\title{
18. PETROLOGY AND COMPOSITION OF THE VOLCANIC BASEMENT OF BOUGAINVILLE GUYOT, SITE 831 ${ }^{1}$
}

\author{
P.E. Baker, ${ }^{2}$ M. Coltorti ${ }^{3}$ L. Briqueu, ${ }^{4}$ T. Hasenaka,${ }^{5}$ E. Condliffe, ${ }^{2}$ and A.J. Crawford ${ }^{6}$
}

\begin{abstract}
The basement of Bougainville Guyot drilled at Site 831 consists of andesitic hyalobreccias derived from a submarine arc volcano. The volcanic sequence has been dated by $\mathrm{K} / \mathrm{Ar}$ at approximately $37 \mathrm{Ma}$. The $121 \mathrm{~m}$ of andesitic hyalobreccias drilled in Hole 831B have been divided into five subunits of two types: one appears to be primary, and the other contains evidence of reworking and a subaerial clastic input. Variations are attributed to fluctuations in water depth. The distinctive hyalobreccias consist of andesitic blebs with chilled margins and peripheral fractures set in a chaotic greenish matrix that is mainly altered glass, with crystals similar to those in the blebs or clasts. Their formation is attributed to violent reaction of andesitic magma discharged into seawater, in perhaps the submarine equivalent of fire-fountaining. There was limited reworking by currents and debris flows on the flanks of the submarine volcano. The andesite shows no significant compositional variation in phenocryst phases throughout the drilled sequence and contains phenocrysts of plagioclase $\left(\mathrm{An}_{88-43}\right)$, clinopyroxene $\left(\mathrm{Ca}_{44} \mathrm{Mg}_{46} \mathrm{Fe}_{10}-\mathrm{Ca}_{41} \mathrm{Mg}_{40} \mathrm{Fe}_{19}\right)$, orthopyroxene $\left(\mathrm{Ca}_{4} \mathrm{Mg}_{79} \mathrm{Fe}_{17}-\mathrm{Ca}_{3} \mathrm{Mg}_{58} \mathrm{Fe}_{39}\right)$, and titanomagnetite. There is a systematic change in volcanic composition with height in the section, from more mafic andesites at the base, to overlying more acid andesites, and strong evidence exists that magma mixing may have played a significant role in the genesis of these lavas. The andesites have affinities with the low-K arc tholeiite series. Trace element and isotopic systematics for these rocks indicate very minor involvement of a LILE-and ${ }^{87} \mathrm{Sr}$-enriched slab-derived fluid in their petrogenesis. This accords with the previous suggestion that Bougainville Guyot forms part of an Eocene proto-island arc developed along the southern side of the d'Entrecasteaux Zone, above a southward-dipping subduction zone.
\end{abstract}

\section{INTRODUCTION}

Bougainville Guyot is a carbonate-capped seamount (Fig. 1) situated at the eastern termination of the South d'Entrecasteaux Chain (SDC). It has some $3 \mathrm{~km}$ of relief and its gently inclined surface is approximately $1 \mathrm{~km}$ below sea level. The guyot is caught in the collision zone between the New Hebrides Island Arc and the d'Entrecasteaux Zone (DEZ). It is in the process of being subducted and/or accreted and is partially embedded in the forearc sediments (Dubois et al., 1988). The surface of the guyot is inclined at about $5^{\circ}$ to the east and lies 1066 meters below seafloor (mbsf) at Site 831. Seismic reflection data had previously indicated that the carbonate cap was approximately $700 \mathrm{~m}$ thick and showed that a $2-\mathrm{km}$-thick debris apron flanked the lower part of the feature (Fisher et al., 1991). Collot et al. (1992) made a series of submersible dives to explore the reefal platform and also recovered island arc tholeiite series basalts and andesites from the southern slopes of the guyot. One basaltic andesite was $\mathrm{K} / \mathrm{Ar}$ dated at $15 \mathrm{Ma}$, which was regarded as a minimum age in view of its altered state. The chalky matrix of a volcanic breccia suggested an age of "uppermost middle Eocene (40-42 Ma)" based on nannofossils. The primary objectives of the present study were to determine the age of the volcanic basement, to investigate its eruptive style, and to establish its magmatic affinities.

\section{ANALYTICAL METHODS}

Microprobe analyses were made at the University of Leeds using a CAMECA SX-50 instrument fitted with three wavelength disper-

\footnotetext{
${ }^{1}$ Greene, H.G., Collot, J.-Y., Stokking, L.B., et al., 1994. Proc. ODP, Sci. Results, 134: College Station, TX (Ocean Drilling Program).

${ }^{2}$ Department of Earth Sciences, University of Leeds, Leeds LS2 9JT, United Kingdom.

${ }^{3}$ Mineralogy Institute, Ferrara University, C.soE. 1 d'Este 32, 44100, Ferrara, Italy.

${ }^{4}$ C.N.R.S. France, Laboratoire de Géochimie Isotopique, U.S.T.L., C.P. 066, 34095 Montpellier Cedex 2, France.

5 Institute of Mineralogy, Petrology and Economic Geology, Faculty of Science, Tohoku University, Aoba, Sendai, Miyagi 980, Japan.

${ }^{6}$ Department of Geology, University of Tasmania, GPO Box 252C, Hobart, Tasmania, Australia 7001.
}

sive spectrometers and a LINK 10/55S energy dispersive system. Analysis conditions were as follows:

1. Silicates and opaque oxides, excluding feldspars. Beam energy: $15 \mathrm{kV}$, beam current $15 \mathrm{nA}$; count times: $\mathrm{Na}, \mathrm{Mg}, \mathrm{Al}, \mathrm{Si}, \mathrm{K}, \mathrm{Ca}$, Ti: all $15 \mathrm{~s}$ on peak, $10 \mathrm{~s}$ background; $\mathrm{Cr}, \mathrm{Mn}, \mathrm{Fe}, \mathrm{Ni}: 30 \mathrm{~s}$ on peak, $20 \mathrm{~s}$ on background.

2. Feldspars and glasses. Beam energy: $15 \mathrm{kV}$, beam current 10 $\mathrm{nA}$; count times for all elements: $10 \mathrm{~s}$ on peak, $10 \mathrm{~s}$ on background. Where necessary, beam broadened to 2 or $3 \mu \mathrm{m}$ to prevent excessive volatilization of $\mathrm{Na}$.

3. Raw counts were corrected for interelemental effects using CAMECA proprietary software.

4. Standards used: Na: albite; $\mathrm{Mg}$ : spinel; $\mathrm{Al}$ : kyanite; $\mathrm{Si}$ : diopside; K: orthoclase; Ca: wollastonite; Ti: sphene; $\mathrm{Cr}$ : chromite; $\mathrm{Mn}$ : rhodonite; Fe: hematite; $\mathrm{Ni}$ : nickel oxide.

$\mathrm{X}$-ray fluorescence (XRF) major and trace element analyses, excluding rare earth elements (REE) were conducted aboard the JOIDES Resolution, at the Institute of Mineralogy, Ferrara University (Italy), and at the Institute of Mineralogy, Petrology and Economic Geology, Tohoku University (Japan). Analytical details are given in Coltorti et al. (this volume). Analytical methods for analyses performed at Tohoku University (including REE) are described in Hasenaka et al. (this volume). Isotopic analyses were carried out at the Laboratoire de Géochimique Isotopique, Université de Montpellier, after leaching using $2 \mathrm{~N} \mathrm{HF}+0.5 \mathrm{~N} \mathrm{HBr}$ mixture and cold $2.5 \mathrm{~N} \mathrm{HCl}$ (see Briqueu et al., this volume).

\section{AGE OF THE VOLCANIC BASEMENT}

Rex (this volume) presents new $\mathrm{K} / \mathrm{Ar}$ age determinations on samples from near the top ( $766 \mathrm{mbsf}$ ) and close to the bottom ( $845 \mathrm{mbsf}$ ) of the drilled section of the volcanic basement. Both determinations were made on fresh andesitic clasts or blebs within the hyaloclastites and are described in detail below. The upper specimen (Sample 134$831 \mathrm{~B}-73 \mathrm{R}-2,30-36 \mathrm{~cm}$ ) yielded an age of $27 \pm 1.0 \mathrm{Ma}$ and the lower one (Sample 134-831B-84R-1, 50-58 cm) an age of $37 \pm 1.0 \mathrm{Ma}$. The 


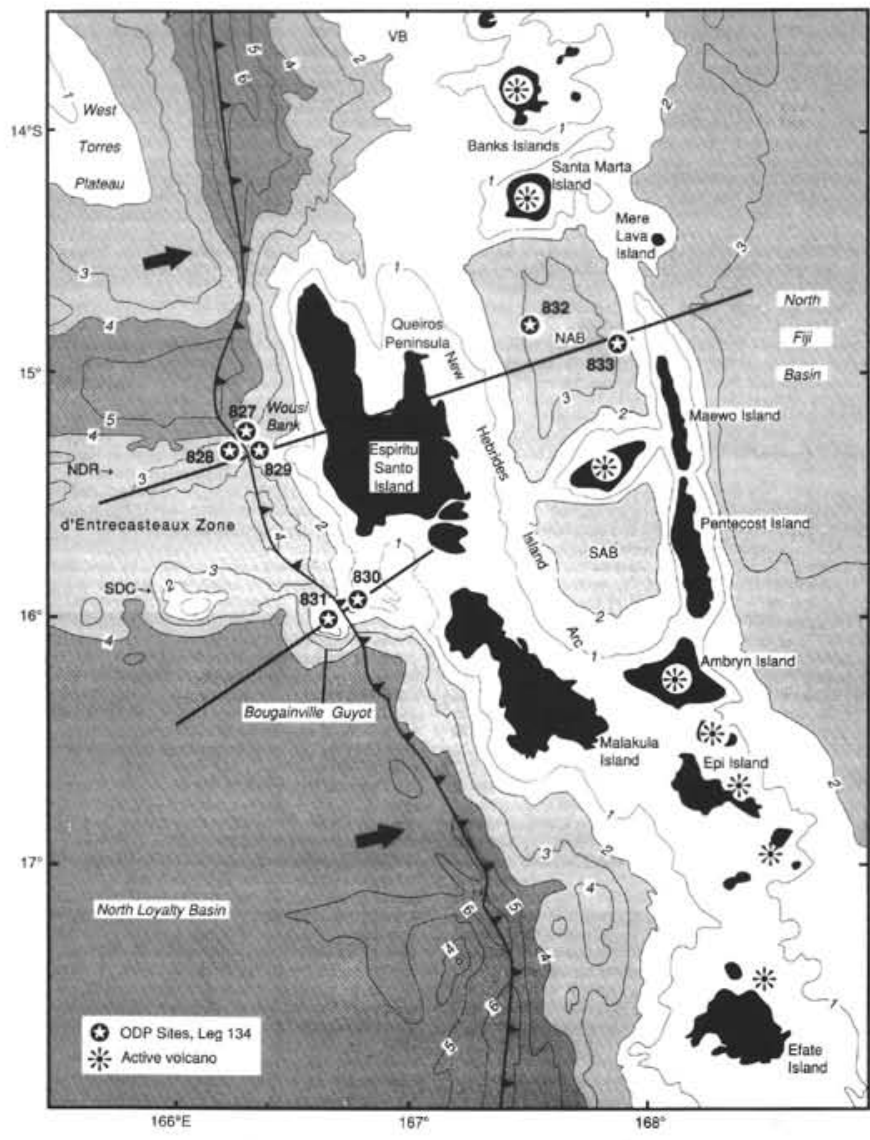

Figure 1. Map of the New Hebrides Island Arc and d'Entrecasteaux Zone showing Bougainville Guyot and Site 831 .

large age difference between these two samples seems improbable since they are separated by a stratigraphic interval of only $79 \mathrm{~m}$ of almost identical volcanic rocks, within which there is no evidence for any significant break in volcanic activity. Paleontological evidence (Collot, Greene, Stokking et al., 1992) suggested a late Oligocene age (23.6-28.2 Ma) for the top of the volcanic sequence based on large foraminifers found in the basal carbonates. However, Quinn et al. (this volume), using ${ }^{87} \mathrm{Sr} /{ }^{86} \mathrm{Sr}$ ratios, infer an age of $36.5 \mathrm{Ma}$ for the lowermost part of the limestone cap. Since the age of $15 \mathrm{Ma}$ obtained on the breccia sample by Collot et al. (1992) was considered suspect in view of alteration and treated as a minimum age, it is disregarded.

Taking all of the above factors into account, the new age of $37 \pm$ 1.0 $\mathrm{Ma}$ is preferred and is likely to reflect the approximate age of the entire volcanic succession that was drilled, since the whole is likely to represent a relatively short timespan. The discrepancy between the two new $\mathrm{K} / \mathrm{Ar}$ ages is probably due to the vitrophyric texture; there is still some fresh glass in both samples, but it is more devitrified in Sample 134-831B-73R-2, 30-36 cm, which would have led to Ar loss and an apparently younger age.

\section{LITHOLOGY}

At $727.5 \mathrm{mbsf}$, the reefal limestones rest on a volcanic sequence that continues to the bottom of the hole at $852 \mathrm{mbsf}$. The contact is marked by a pale orange-brown oxidized zone attributed to subaerial weathering and regarded as a bole. The volcanic succession, designated as lithostratigraphic Unit IV, consists almost entirely of primary andesitic hyalo-breccias with only occasional evidence of reworking. The term hyalo-breccia was used simply to denote that glass or its alteration products constitute a significant proportion of the rock and that the material has been substantially fragmented. The association might also be referred to as hyaloclastite although the rocks lack the angular glass clasts and slivers that are sometimes implied by this term (e.g., Fisher and Schmincke, 1984). Palagonite breccia is a less appropriate general term, since thin-section examination shows that relatively little of the glass has been altered to characteristically yellow palagonite and its alteration products.

In hand specimen the hyalo-breccias are very striking rocks (Fig. 2 ), consisting mainly of gray fragments or clasts of andesite in a greenish matrix. The proportion of clasts to matrix is not constant throughout the sequence, with the volume of clasts varying between $20 \%$ and $50 \%$ of the total rock. The term "clast" is not ideal but is used to denote the more coherent gray pieces of lava dispersed throughout the matrix-supported breccia. Many of the clasts are rounded and others have irregular or sometimes wispy shapes, suggesting that they were in a plastic state at the time of their incorporation into the matrix; for these the term "bleb" would be more suitable. The clasts are commonly of the order of $1 \mathrm{~cm}$ in diameter but they range down to about $2 \mathrm{~mm}$. Others exceed the diameter of the core $(5.5 \mathrm{~cm})$ and were recovered as isolated pieces, so that contact relations were not visible. These are probably fragments of much larger clasts or blebs, but they are probably not particularly abundant.

The clasts are composed of porphyritic andesite with phenocrysts of plagioclase, orthopyroxene (brownish), and clinopyroxene (dark green). The matrix usually ranges through various shades of green, but is sometimes gray; pastel tones of mauve or pale red are more common towards the top of the succession. Crystals of feldspar, pyroxenes, and opaque minerals are disseminated through the matrix and are clearly visible in the hand specimen. The matrix is veined and also has open fractures and vugs that tend to be coated with a white mineral, probably zeolite. Small prismatic crystals, also thought to be zeolites, may sometimes be seen in these cavities. The irregular development of secondary minerals adds to the patchy texture of the hand specimen. The contact of the clasts or blebs with the matrix is usually but, not invariably, marked by a thin $(<1 \mathrm{~mm})$ white rind or corona that stands out as a very conspicuous feature of the hand specimen.

Five subunits were distinguished on the basis of shipboard visual core descriptions, and these are consistent with subsequent petrologi$\mathrm{cal}$ and geochemical studies. The original conclusion had been that variations in the sequence reflected differences in the water depths at which eruptions had occurred. There was thus a possibility that this might also be manifested in differences of vesicle size or abundance, but there is no evidence to support such a contention. A second possibility is that water pressure might have controlled the extent of degassing of the glass. Unfortunately, attempts to measure the sulphur content of glass in the clasts were unsuccessful, owing to the very low concentrations of this element.

The five subunits have many features in common and the boundaries between them are mainly gradational. Two categories of subunit were recognized. One group, comprising Subunits IVB and IVD, is composed exclusively of relatively clearly defined gray clasts or blebs in a greenish matrix, and these are regarded as primary eruptive products, hyaloclastites or hyalo-breccias. The other group (Subunits IVA, IVC, and IVE) contains similar primary volcanics but also includes oxidized fragments and reworked horizons. The alternation of the groups is interpreted as an indication of a cyclicity of the eruptive or depositional environment that is probably best explained by changes in water depth. Specific features recorded for each of the subunits follow.

\section{Subunit IVA (727-741 mbsf)}

The bole and other strongly oxidized horizons appearing close to the contact with the overlying carbonates pass downwards to pale brown and brownish gray hyaloclastite breccias. Larger clasts of dark gray andesite become progressively more abundant with depth and make up about $25 \%$ of the rock near the base of the subunit. There are horizons (e.g., $738 \mathrm{mbsf}$ ) where the primary hyaloclastite material has clearly been reworked to form thin beds of volcaniclastic grit and sandstone. 


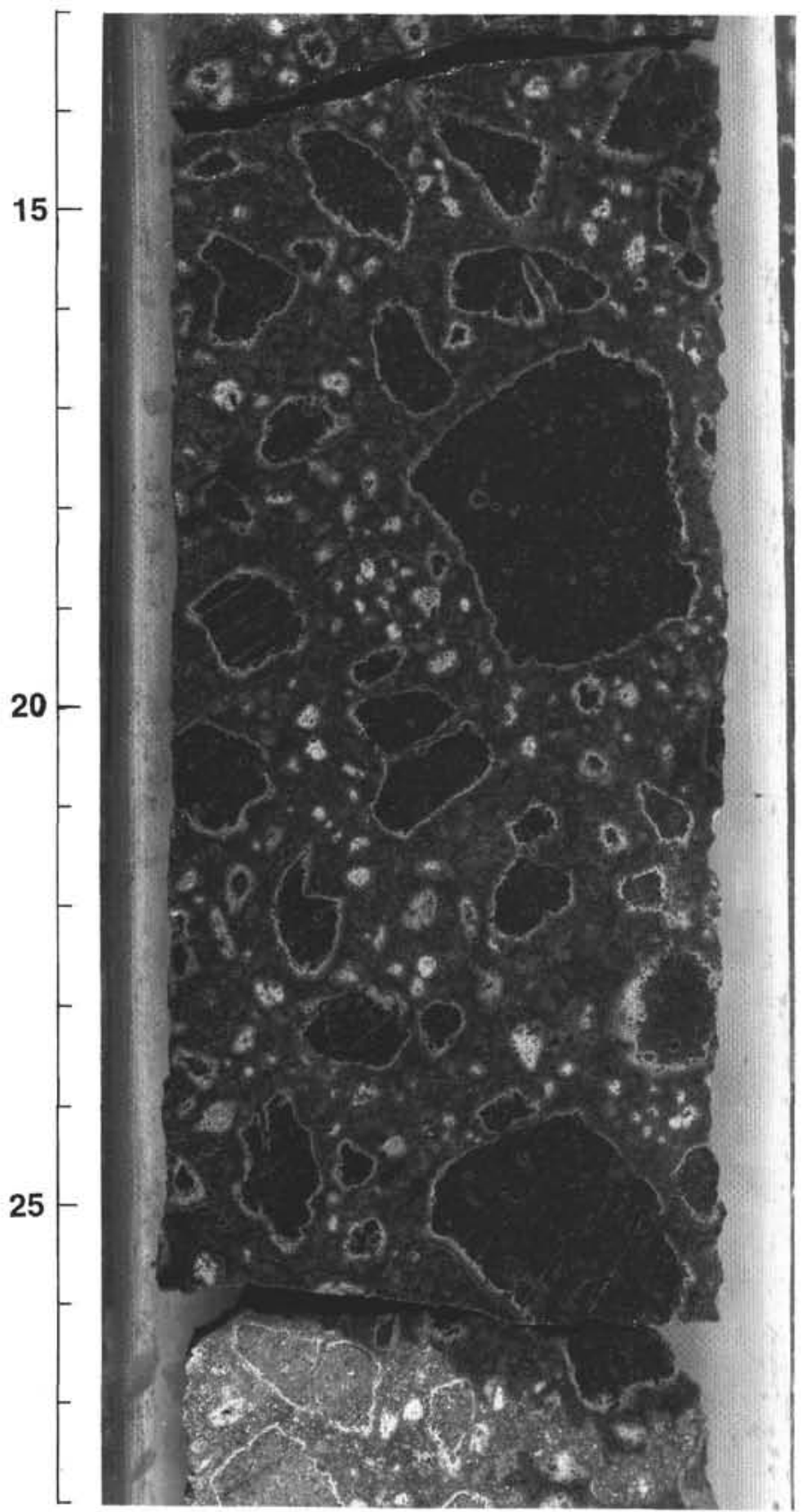

Figure 2. Photograph of hyalo-breccia Sample 134-831B-83R-2, 13-28 cm, showing andesitic clasts and blebs with peripheral zeolite-filled fractures, enclosed in altered glass.

\section{Subunit IVB (741-789 mbsf)}

This consists of hyalo-breccias in which sub-rounded or wispy andesitic blebs, are set within a pale green matrix. Most of these blebs have a conspicuous white corona, originally thought to be a reaction rim, which is described in detail later on the basis of thin-section examination.

\section{Subunit IVC (789-822 mbsf)}

This subunit is marked by coarser-grained breccias that include pale reddish brown fragments. The rocks become more poorly sorted towards the bottom of the subunit and the frequency of oxidized clasts increases. The clasts are set in a variegated matrix that is pale red to pale gray in color. Interspersed within the breccias are thin beds of volcaniclastic grits and sandstones. In the interval 798-802 mbsf there are beds of gray clast-rich breccia where the clasts constitute up to about $40 \%$ of the rock and range in diameter from $1 \mathrm{~cm}$ to at least 15 $\mathrm{cm}$ in the maximum observable dimension along the length of the core. However, most of the pieces are about $2 \mathrm{~cm}$ across. The clasts show a greater variety of shapes than in Subunit IVB, ranging from sub-angular to sub-rounded. Other clasts are more rounded or wispy in outline, with indistinct boundaries and a pale marginal zone or halo about 2 to $4 \mathrm{~mm}$ wide. In some instances, the gray clasts have a thin $(0.5 \mathrm{~mm})$ white rim that is, in turn, enclosed by an outer pale greenish gray zone before a fairly sharp contact with the breccia matrix. The relationship clearly suggests some kind of reaction has taken place at the margins of the clasts. However, the incidence of these peripheral zones or reaction rinds is significantly less within this subunit compared with those that occur above and below. The matrix consists of altered glass, small andesitic lithics of similar composition to the larger clasts, and crystals of plagioclase and pyroxenes.

\section{Subunit IVD (822-838 mbsf)}

This is a more uniform subunit consisting almost entirely of clearly defined gray blebs with conspicuous white coronas or reaction rims in a greenish gray matrix. However, towards the bottom of the subunit (837 mbsf), the blebs or clasts become more irregular, wispy and diffuse, although still retaining white marginal coronas. At this level the blebs have become more abundant and constitute about $50 \%$ of the volume of the rock. Fractures and vugs in the matrix contain grayish green secondary minerals, which are probably celadonite and zeolites.

\section{Subunit IVE (838-852 mbsf)}

At this deeper level there is a return to the characteristics of oxidation and reworking. Pale reddish and more angular fragments occur and marginal coronas are less common, and the matrix becomes a paler shade of greenish gray. Finally these hyalo-breccias pass downwards into poorly consolidated volcaniclastic grits and a crossbedded sandstone.

\section{PETROGRAPHY}

\section{Clasts}

This section describes the petrographic features of the interior of the clasts or blebs away from the marginal reaction zone that separates them from the hyaloclastite matrix. There are essentially two kinds of variation in the clasts:

1. The proportion of phenocrysts varies from $20 \%$ to $40 \%$ of total rock volume.

2. The groundmass of the clasts varies from instances where there is an appreciable amount (15\%) of fresh interstitial glass (e.g., Sample 134-831B-83R-2, 59-62 cm) to cases where no glass is detectable and the groundmass is dark and turbid (e.g., Sample 134-831B-84R-1, $50-58 \mathrm{~cm})$.

The clasts are porphyritic two-pyroxene andesites in which the most abundant phenocrysts are plagioclase, followed by clinopyroxene, orthopyroxene, and also microphenocrysts of opaque oxides. Taking Sample 134-831B-73R-2, 30-36 cm, as representative, the phenocrysts make up about $35 \%$ of the total rock. Plagioclase phenocrysts $(20 \%, 0.5-4 \mathrm{~mm})$ are euhedral to subhedral and show pronounced oscillatory zoning. Some plagioclases are intergrown as glomeroporphyritic clusters or occur in close association with the pyroxenes. A few have strongly corroded penultimate zones, suggesting that they were out of equilibrium with the host magma immediately before eruption and crystallization of the outermost rim. Next in abundance are clinopyroxene phenocrysts $(7 \%, 0.5-2.5 \mathrm{~mm})$, which are subhedral, 
strongly zoned and contain opaque inclusions. Orthopyroxenes (5\%, $0.3-2 \mathrm{~mm}$ ) tend to be more euhedral and are slightly less abundant. There are also sparse microphenocrysts of titanomagnetite $(<1 \%$, $0.1-0.2 \mathrm{~mm}$ ). Clusters (2-4 mm in diameter) of similar minerals are probably cognate inclusions, the product of prior crystallization of the same magma on the walls of feeder dikes or conduits. In this case, the matrix is composed of interlocking plagioclase laths, small pyroxenes, abundant opaque oxide grains, and an interstitial silica mineral (quartz or cristobalite). In other cases (e.g., Sample 134-831B-83R-2, 59-62 $\mathrm{cm}$ ) there is a pale mesostasis of rhyodacite glass with crystallites.

\section{Contact Zone}

Usually the clasts or blebs show a chilled margin about $2 \mathrm{~mm}$ wide into which the phenocrysts pass unchanged. The main difference is that the groundmass crystallites are smaller than in the interior and also that the matrix is more heavily charged with finely disseminated opaque oxide minerals. Presumably as a consequence of differential cooling and contraction, the chilled rind is usually separated from the main body of the clast or bleb by a fracture $(<1 \mathrm{~mm}$ wide) (e.g., in Sample 134-831B-83R-2, 59-62 cm). The infilling of this peripheral fracture by zeolites creates the white corona that is such a conspicuous feature of the hand specimen. Further outwards is a less distinctly defined zone in which shattered plagioclase phenocrysts feature prominently. Some plagioclase phenocrysts are intensely fractured, though largely retaining their original shape, but others have disintegrated into sharp clasts and shards. Altered glass fills the fractures and encloses the broken fragments. The zone of shattered feldspars is not responsible for the white rims of the blebs as suggested in Collot, Greene, Stokking, et al. (1992).

\section{Hyalo-breccia Matrix}

The green matrix contains the same mineral assemblage as the clasts and blebs that it encloses. This is to be expected since available mineral chemical data suggest that it formed from the same magma as the clasts but involved a greater degree of quench fragmentation induced by contact with seawater. The clasts simply represent the residual coherent blebs of magma that remained intact owing to the protection afforded by their chilled rinds. Mineral analyses have confirmed that identical compositional ranges are shown by the phases in the clasts and the matrix. The main difference is that, within the breccia matrix, phenocrysts tend to be fractured and fragmented. Although plagioclase was most susceptible to break-up, the other phases also show evidence of fracturing. As in the contact zone, there is a complete range from incipient cracking to total disintegration. The crystals are embedded within a chaotic matrix consisting primarily of streaky altered and fractured glass. There is evidence of cross-cutting relationships suggesting successive injections of magma. Throughout, there is patchy alteration to yellowish palagonite, zeolites, clay minerals, and iron oxides. The matrix also contains abundant pieces of broken clast material and fragments of chilled rinds. These features are especially conspicuous, for instance, in Sample 134-831B-83R-2, 59-62 cm (Fig. 3).

\section{MINERAL CHEMISTRY}

Although individual mineral phases are by no means uniform in their chemical compositions, the range of variation exhibited is essentially the same throughout the entire $121 \mathrm{~m}$ of drilled volcanic rocks. There is no suggestion of any systematic or progressive change with stratigraphic level. The mineral chemistry is therefore treated as being generally applicable to the sequence as a whole.

Orthopyroxenes are mostly hypersthene with low $\mathrm{Al}_{2} \mathrm{O}_{3}$ contents $(0.6-1.8 \%)$, but show a large overall compositional range (Table 1; Fig. 4), from $\mathrm{Ca}_{4} \mathrm{Mg}_{79} \mathrm{Fe}_{17}$ to $\mathrm{Ca}_{3} \mathrm{Mg}_{58} \mathrm{Fe}_{39}$. Almost invariably, they show complex and dominantly reversed zoning, with typically fairly

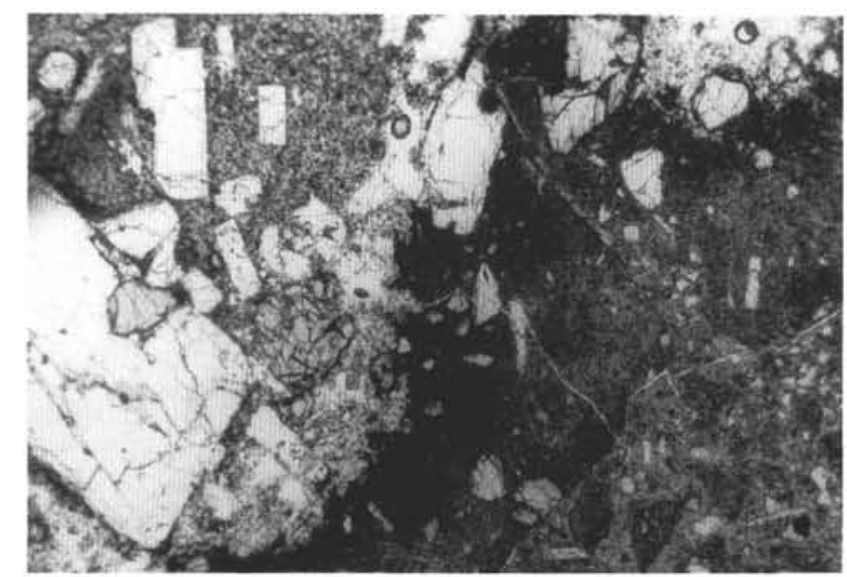

Figure 3. Photomicrograph of Sample 134-831B-83R-2, 59-62 cm.

large and relatively Fe-rich cores followed by a more magnesian overgrowth, and then a series of oscillatory zones before a final Ferich rim. For example, in Sample 134-831B-70R, 36-37 cm, a core of $\mathrm{Ca}_{3} \mathrm{Mg}_{62} \mathrm{Fe}_{35}$ is enclosed by an overgrowth of $\mathrm{Ca}_{4} \mathrm{Mg}_{78} \mathrm{Fe}_{18}$ and then a series of oscillatory zones, terminating eventually in a rim of $\mathrm{Ca}_{4} \mathrm{Mg}_{71} \mathrm{Fe}_{25}$. In Sample 134-831B-73R-2, 30-36 cm, a core of $\mathrm{Ca}_{3} \mathrm{Mg}_{63} \mathrm{Fe}_{34}$ is followed by a slightly more magnesian border of $\mathrm{Ca}_{3} \mathrm{Mg}_{66} \mathrm{Fe}_{31}$, a series of oscillatory zones in which the most magnesian composition is $\mathrm{Ca}_{4} \mathrm{Mg}_{75} \mathrm{Fe}_{21}$, and a return to an $\mathrm{Fe}$-rich outer rind of $\mathrm{Ca}_{4} \mathrm{Mg}_{61} \mathrm{Fe}_{35}$. Patches and sectors of clinopyroxene are frequently developed within and around the orthopyroxenes. For instance, a sector within the core of an orthopyroxene in Sample 134-831B-70R, $36-37 \mathrm{~cm}$, is clinopyroxene with the composition $\mathrm{Ca}_{43} \mathrm{Mg}_{40} \mathrm{Fe}_{17}$. In Sample 134-831B-73R-2, 30-36 cm, an orthopyroxene crystal with a core of $\mathrm{Ca}_{3} \mathrm{Mg}_{63} \mathrm{Fe}_{34}$, mantled by a more magnesian overgrowth of $\mathrm{Ca}_{4} \mathrm{Mg}_{74} \mathrm{Fe}_{22}$, shows the preferential development of clinopyroxene $\left(\mathrm{Ca}_{43} \mathrm{Mg}_{40} \mathrm{Fe}_{17}\right)$ on some faces (Fig. 5).

Clinopyroxene phenocrysts are often twinned and usually show complex and patchy zonation. They are augites (Table 2) showing a fairly restricted compositional spread (Fig. 4), in the range $\mathrm{Ca}_{44} \mathrm{Mg}_{46} \mathrm{Fe}_{10}$ to $\mathrm{Ca}_{41} \mathrm{Mg}_{40} \mathrm{Fe}_{19}$. As with the orthopyroxenes, there is a tendency for reversed zoning to predominate in the inner part of a crystal with subsequent thin oscillatory zones and then a final more Fe-rich rim. For example, in Sample 134-831B-70R-2, 94-98 cm, a clinopyroxene has a core of $\mathrm{Ca}_{42} \mathrm{Mg}_{40} \mathrm{Fe}_{18}$, an overgrowth of $\mathrm{Ca}_{45} \mathrm{Mg}_{46} \mathrm{Fe}_{9}$, and a rim of $\mathrm{Ca}_{42} \mathrm{Mg}_{41} \mathrm{Fe}_{17}$. Groundmass pyroxenes in the clasts range

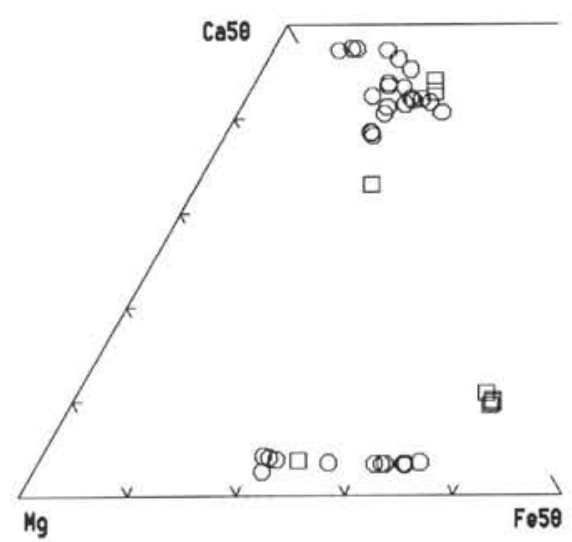

Figure 4. Pyroxene quadrilateral showing compositions of pyroxenes from Sample $134-831 B-73 R-2,30-36 \mathrm{~cm}$. This sample represents virtually the entire range of pyroxene compositions found in the volcanic rocks of Bougainville Guyot. Phenocrysts shown by circles; groundmass pyroxenes by squares. 


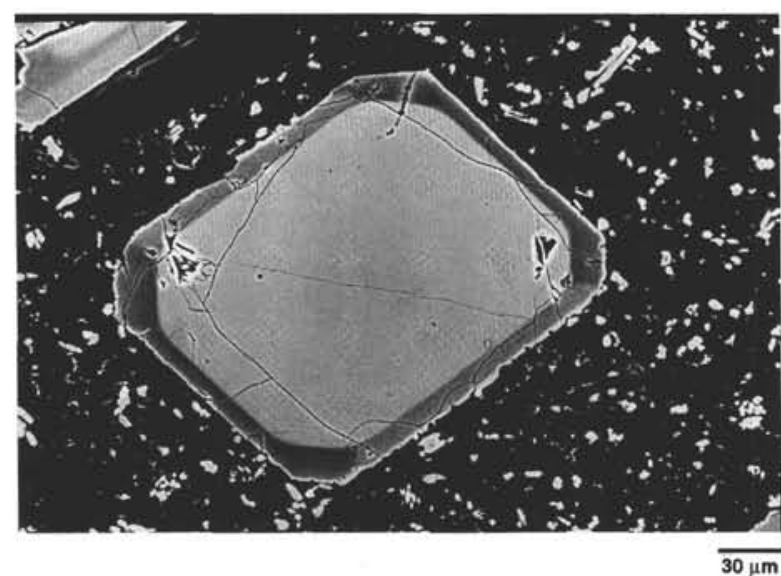

Figure 5. SEM photograph showing orthopyroxene phenocryst in Sample 134-831B-73R-2, 30-36 cm, with preferential development of clinopyroxene $\left(\mathrm{Ca}_{43} \mathrm{Mg}_{40} \mathrm{Fe}_{17}\right)$ on some faces.

from subcalcic augites (e.g., $\mathrm{Ca}_{34} \mathrm{Mg}_{46} \mathrm{Fe}_{20}$ to $\mathrm{Ca}_{24} \mathrm{Mg}_{50} \mathrm{Fe}_{26}$ in Sample $134-831 \mathrm{~B}-84 \mathrm{R}-1,50-58 \mathrm{~cm}$ ) to pigeonite (e.g., $\mathrm{Ca}_{9} \mathrm{Mg}_{57} \mathrm{Fe}_{34}$ in Sample 134-831B-83R-2, 59-62 cm). The $\mathrm{Al}_{2} \mathrm{O}_{3}$ contents in the clinopyroxene phenocrysts are mostly in the range $1 \%-3 \%$, averaging around $1.5 \%$. The highest contents (e.g., $3.16 \% \mathrm{Al}_{2} \mathrm{O}_{3}$ in Sample 134-831B-70R-3, 36-37 cm) tend to be in the clinopyroxene sector zones within the orthopyroxenes, and the lowest figures, about $0.5 \%$, in the groundmass subcalcic augites and pigeonites. Clinopyroxene phenocryst $\mathrm{TiO}_{2}$ contents are also typically around $0.5 \%$, with a range between $0.2 \%$ and $0.6 \%$.

Plagioclase phenocrysts (Table 3 ) show highly variable oscillatory zoning. The most extreme range is in Sample 134-831B-73R-2, $30-36 \mathrm{~cm}$, in which there is a core as calcic as $\mathrm{An}_{88}$ and a rim of $\mathrm{An}_{43}$. In Sample 134-831B-70R-3, 36- $37 \mathrm{~cm}$, one of the cores reaches $\mathrm{An}_{78}$ and the rim $\mathrm{An}_{55}$ but there are other phenocrysts in the same rock where the core to rim sequence is $\mathrm{An}_{56}-\mathrm{An}_{45}-\mathrm{An}_{53}$. Plagioclase core compositions are mostly in the labradorite range, with a few more calcic examples. However, most of the plagioclases analyzed have a distinctive highly zoned periphery with the rim being decidedly more calcic than the penultimate zone (e.g., $\mathrm{An}_{47}$ to $\mathrm{An}_{55}$ in Sample 134831B-70R-3, 36- $37 \mathrm{~cm}$ ).

The opaque oxide minerals are mostly titanomagnetites (Table 4), although there are rare instances of ilmenite with titanomagnetite overgrowths.

The strong oscillatory zoning in the plagioclase phenocrysts, and the pronounced reverse-zoning in the pyroxene phenocrysts argue strongly for magma mixing (recharge?) and phenocryst recycling to have been important processes in the petrogenesis of these lavas. It might also be possible that some of this variation is due to periodic changes in the volatile budget of the subvolcanic magma chamber, due to degassing, or flooding of the magma chamber by sea-water during major magma chamber-emptying eruptions.

\section{WHOLEROCK GEOCHEMISTRY}

Wholerock analyses are given in Table 5 , recalculated volatilefree. The $\mathrm{SiO}_{2}$ content of the clasts or blebs in the drilled sequence ranges from $57.8 \%$ to $62.5 \%$, within the andesite compositional range. Samples collected during the SEAPSO 1 cruise in 1985 and reported by Collot et al. (1992) extend into the basaltic range.

Shipboard studies (Collot, Greene, Stokking, et al., 1992) suggested that there was no systematic variation of $\mathrm{SiO}_{2}$ or any other oxides with stratigraphic level within the $121 \mathrm{~m}$ of drilled section. However, plots using the total available data (Figs. 6 and 7) show that, excluding the acid andesite from the bottom of the hole ( $848.45 \mathrm{mbsf}$ ), there is a broad but regular increase in $\mathrm{MgO}$ and $\mathrm{CaO}$, and decrease in $\mathrm{SiO}_{2}$ and $\mathrm{TiO}_{2}$ with depth in the drilled section. More mobile elements such as $\mathrm{K}, \mathrm{Na}$, and other alkali elements, show no systematic change and are presumed to have been altered to some degree from their original values. Rocks recovered by Collot et al. (1992) from between 2800 and $3000 \mathrm{~m}$ below sea level on the flanks of the seamount include basaltic breccia fragments and isolated clasts that could have originated from anywhere within the volcanic succession, and all are altered. One of their samples (D1 F) has $\mathrm{Mg} \#=80$ and must represent a mafic phenocryst-rich sample in which pyroxenes and olivine have accumulated.

Plots of $\mathrm{MgO}, \mathrm{FeO}$, $\mathrm{CaO}$, and $\mathrm{TiO}_{2}$ against $\mathrm{SiO}_{2}$ are shown in Figure 7. It is clear that the lavas drilled below $800 \mathrm{mbsf}$ have distinctly lower $\mathrm{FeO}^{*}$ and $\mathrm{TiO}_{2}$ contents at any $\mathrm{SiO}_{2}$ level than those higher in the drilled sequence. The four least-altered samples reported by Collot et al. (1992) include basalts and andesites and on the basis of Figure 7 would seem to correlate better with the uppermost drilled lavas than those deeper in the drilled section.

The evolved andesite at the base of the hole may represent a differentiated unit from the upper part of a zoned subvolcanic magma chamber, and the following mafic andesites below $800 \mathrm{mbsf}$ may be from more crystal-rich mafic levels, deeper in the magma chamber, but all related to the same parental magma. A plot of $\mathrm{TiO}_{2}$ vs. $\mathrm{SiO}_{2}$ (Fig. 7D) shows that the basal andesites ( $~ 800 \mathrm{mbsf})$ define a typical arc andesite differentiation trend of $\mathrm{TiO}_{2}$ decreasing with fractionation. They are clearly separated from the overlying andesites, with which they are unlikely to be directly comagmatic. At $60 \% \mathrm{SiO}_{2}$, the upper, more differentiated lavas are notably more depleted in $\mathrm{CaO}$ and enriched in $\mathrm{TiO}_{2}$ and $\mathrm{FeO}$ *. A transition zone from the lower mafic andesites to the upper acid andesites occurs between 780 and $800 \mathrm{~m}$, although on the basis of $\mathrm{TiO}_{2}$ contents, the transitional lavas would seem to be related to the upper lavas.

As noted above, lack of any significant correlation between $\mathrm{K}_{2} \mathrm{O}$ contents and fractionation indices suggests that limited mobility of $\mathrm{K}_{2} \mathrm{O}$ (and related elements) may have occurred during alteration of these samples, accompanying high-temperature interaction with seawater, and post-burial modification. However, at 3\%-4\% MgO, most samples have around $0.5 \% \mathrm{~K}_{2} \mathrm{O}$, and on this basis and their $\mathrm{K}_{2} \mathrm{O} / \mathrm{SiO}_{2}$ values, all Bougainville Guyot andesites belong to the low-K series of Basaltic Volcanism Study Project (BVSP; 1981). This inference is strongly supported by the flat chondrite-normalized REE patterns (Fig. 8 ) and the MORB-like Nd-Sr isotopic ratios.

Rare earth elements (REE) have been determined (Table 6) on three andesites from the Bougainville Guyot, one each from the basal andesites ( $>800 \mathrm{mbsf}$ ), the transitional lavas ( 780 and $800 \mathrm{mbsf}$ ), and from the upper andesites (737-780 mbsf). Chondrite-normalized patterns (Fig. 8) are rather unusual, with chondrite normalized La/Sm values (i.e., $[\mathrm{La} / \mathrm{Sm}]_{\mathrm{N}}$ ) close to or just less than 1 , but $(\mathrm{La} / \mathrm{Yb})_{\mathrm{N}}$ values from 1.3 to 1.9 , with the lower andesites having less LREE-enrichment that the upper andesites. They thus differ from the typical regularly LREE-enriched patterns characteristic of most orogenic andesites (e.g., Woodhead, 1989). Few low-K series arc tholeiitic lavas have REE patterns similar to those from the Bougainville Guyot andesites, although andesites from the low-K tholeiite series of St. Kitts in the Lesser Antilles (Baker, 1984), the South Sandwich Islands (P. Baker, unpubl. data, 1992), and the Korobasaga Volcanic Series of the Lau Ridge remnant arc (Cole et al., 1990) have patterns fairly close to those of the Bougainville Guyot rocks. Interestingly, similar REE patterns to the Bougainville Guyot andesites are more frequently recorded from basalts erupted during the early stages of backarc basin opening, for example in the Sumisu Rift (Ikeda and Yuasa, 1989; Hochstaedter et al., 1990) and the Guaymas Basin of the Gulf of California (Saunders et al., 1982). However, andesites are absent, or considerably less voluminous than basalts in these incipient backarc opening settings.

MORB-normalized trace element patterns (Pearce, 1983) for three representative andesites from Bougainville Guyot are shown in Figure 9A, and in Figure 9B comparative patterns are illustrated for several other Southwest Pacific low- to medium-K series andesites with simi- 
Table 1. Electron microprobe analyses of orthopyroxene phenocrysts from Bougainville Guyot andesitic lavas, Hole 831B.

\begin{tabular}{|c|c|c|c|c|c|c|c|c|c|c|c|c|c|c|c|c|c|c|}
\hline $\begin{array}{l}\text { Core, section: } \\
\text { Interval }(\mathrm{cm}) \text { : } \\
\text { Zone: }\end{array}$ & $\begin{array}{c}70 \mathrm{R}-2 \\
94-98 \\
\text { core }\end{array}$ & $\begin{array}{c}70 \mathrm{R}-2 \\
94-98 \\
\operatorname{rim}\end{array}$ & $\begin{array}{l}70 \mathrm{R}-2 \\
94-98 \\
\text { core }\end{array}$ & $\begin{array}{l}70 \mathrm{R}-2 \\
94-98 \\
\text { rim }\end{array}$ & $\begin{array}{l}70 \mathrm{R}-2 \\
94-98 \\
\text { core }\end{array}$ & $\begin{array}{l}70 \mathrm{R}-2 \\
94-98 \\
\text { inter }\end{array}$ & $\begin{array}{c}\text { 70R-2 } \\
94-98 \\
\text { rim }\end{array}$ & $\begin{array}{l}70 \mathrm{R}-2 \\
94-98 \\
\text { core }\end{array}$ & $\begin{array}{l}70 \mathrm{R}-2 \\
94-98 \\
\text { inter }\end{array}$ & $\begin{array}{c}70 \mathrm{R}-3 \\
36-37 \\
\text { core }\end{array}$ & $\begin{array}{c}70 \mathrm{R}-3 \\
36-37 \\
\text { inter }\end{array}$ & $\begin{array}{l}70 R-3 \\
36-37 \\
\text { inter }\end{array}$ & $\begin{array}{c}70 R-3 \\
36-37 \\
\text { core }\end{array}$ & $\begin{array}{l}70 \mathrm{R}-3 \\
36-37 \\
\text { inter }\end{array}$ & $\begin{array}{c}70 \mathrm{R}-3 \\
36-37 \\
\mathrm{rim}\end{array}$ & $\begin{array}{l}73 \mathrm{R}-2 \\
30-36 \\
\text { core }\end{array}$ & $\begin{array}{c}73 \mathrm{R}-2 \\
30-36 \\
\text { rim }\end{array}$ & $\begin{array}{c}73 R-2 \\
30-36 \\
\text { inter }\end{array}$ \\
\hline $\mathrm{SiO}_{2}$ & 52.64 & 54.91 & 52.44 & 54.95 & 52.66 & 54.54 & 53.79 & 52.89 & 54.21 & 52.60 & 55.05 & 55.22 & 52.79 & 52.99 & 52.23 & 54.19 & 54.01 & 53.54 \\
\hline $\mathrm{TiO}_{2}^{2}$ & 0.31 & 0.24 & 0.26 & 0.18 & 0.21 & 0.16 & 0.21 & 0.25 & 0.26 & 0.22 & 0.15 & 0.12 & 0.21 & 0.33 & 0.22 & 0.25 & 0.28 & 0.32 \\
\hline $\mathrm{Al}_{2} \mathrm{O}_{3}$ & 0.70 & 0.91 & 0.69 & 1.19 & 0.64 & 0.69 & 0.60 & 0.63 & 0.63 & 1.04 & 1.47 & 1.35 & 0.83 & 1.00 & 0.54 & 0.55 & 0.78 & 0.79 \\
\hline $\mathrm{Cr}_{2} \mathrm{O}_{3}$ & 0.00 & 0.11 & 0.03 & 0.01 & 0.00 & 0.03 & 0.02 & 0.00 & 0.00 & 0.09 & 0.15 & 0.03 & 0.04 & 0.00 & 0.00 & 0.00 & 0.00 & 0.00 \\
\hline $\mathrm{Fe}_{2} \mathrm{O}_{3}$ & 1.41 & 1.38 & 0.89 & 0.22 & 1.37 & 1.33 & 0.37 & 0.00 & 0.00 & 0.60 & 0.00 & 0.00 & 2.30 & 2.17 & 1.41 & 0.00 & 0.00 & 0.17 \\
\hline $\mathrm{FeO}$ & 20.31 & 12.80 & 21.29 & 13.54 & 20.42 & 12.75 & 17.25 & 22.63 & 18.13 & 21.06 & 11.88 & 12.70 & 19.21 & 17.93 & 22.70 & 19.79 & 19.86 & 19.30 \\
\hline $\mathrm{MnO}$ & 0.56 & 0.40 & 0.53 & 0.31 & 0.55 & 0.30 & 0.38 & 0.54 & 0.35 & 0.49 & 0.25 & 0.36 & 0.46 & 0.43 & 0.77 & 0.52 & 0.53 & 0.38 \\
\hline $\mathrm{MgO}$ & 22.48 & 28.23 & 21.62 & 27.80 & 22.45 & 27.99 & 25.18 & 21.39 & 24.64 & 22.17 & 28.54 & 28.21 & 23.26 & 24.08 & 20.75 & 23.31 & 23.13 & 23.40 \\
\hline $\mathrm{CaO}$ & 1.59 & 1.71 & 1.76 & 1.79 & 1.56 & 1.75 & 1.48 & 1.42 & 1.66 & 1.51 & 1.96 & 1.78 & 1.53 & 1.63 & 1.53 & 1.68 & 1.68 & 1.68 \\
\hline $\mathrm{Na}_{2} \mathrm{O}$ & 0.54 & 0.04 & 0.07 & 0.04 & 0.04 & 0.03 & 0.03 & 0.03 & 0.01 & 0.02 & 0.02 & 0.04 & 0.05 & 0.06 & 0.05 & 0.00 & 0.01 & 0.03 \\
\hline Total & 100.54 & 100.73 & 99.58 & 100.02 & 99.89 & 99.57 & 99.31 & 99.78 & 99.89 & 99.80 & 99.47 & 99.81 & 100.67 & 100.62 & 100.20 & 100.29 & 100.28 & 99.61 \\
\hline Wo & 3.16 & 3.28 & 3.55 & 3.48 & 3.11 & 3.38 & 2.92 & 2.88 & 3.30 & 3.04 & 3.83 & 3.52 & 3.01 & 3.19 & 3.07 & 3.32 & 3.34 & 3.34 \\
\hline En & 62.37 & 75.14 & 60.77 & 75.20 & 62.31 & 75.15 & 69.33 & 60.40 & 68.05 & 62.18 & 77.64 & 71.33 & 63.61 & 65.71 & 58.06 & 64.88 & 64.62 & 65.47 \\
\hline Fs & 34.47 & 21.58 & 35.68 & 21.32 & 34.58 & 21.47 & 27.75 & 36.73 & 29.62 & 34.78 & 18.53 & 25.15 & 33.38 & 31.10 & 38.86 & 31.80 & 32.04 & 31.20 \\
\hline
\end{tabular}
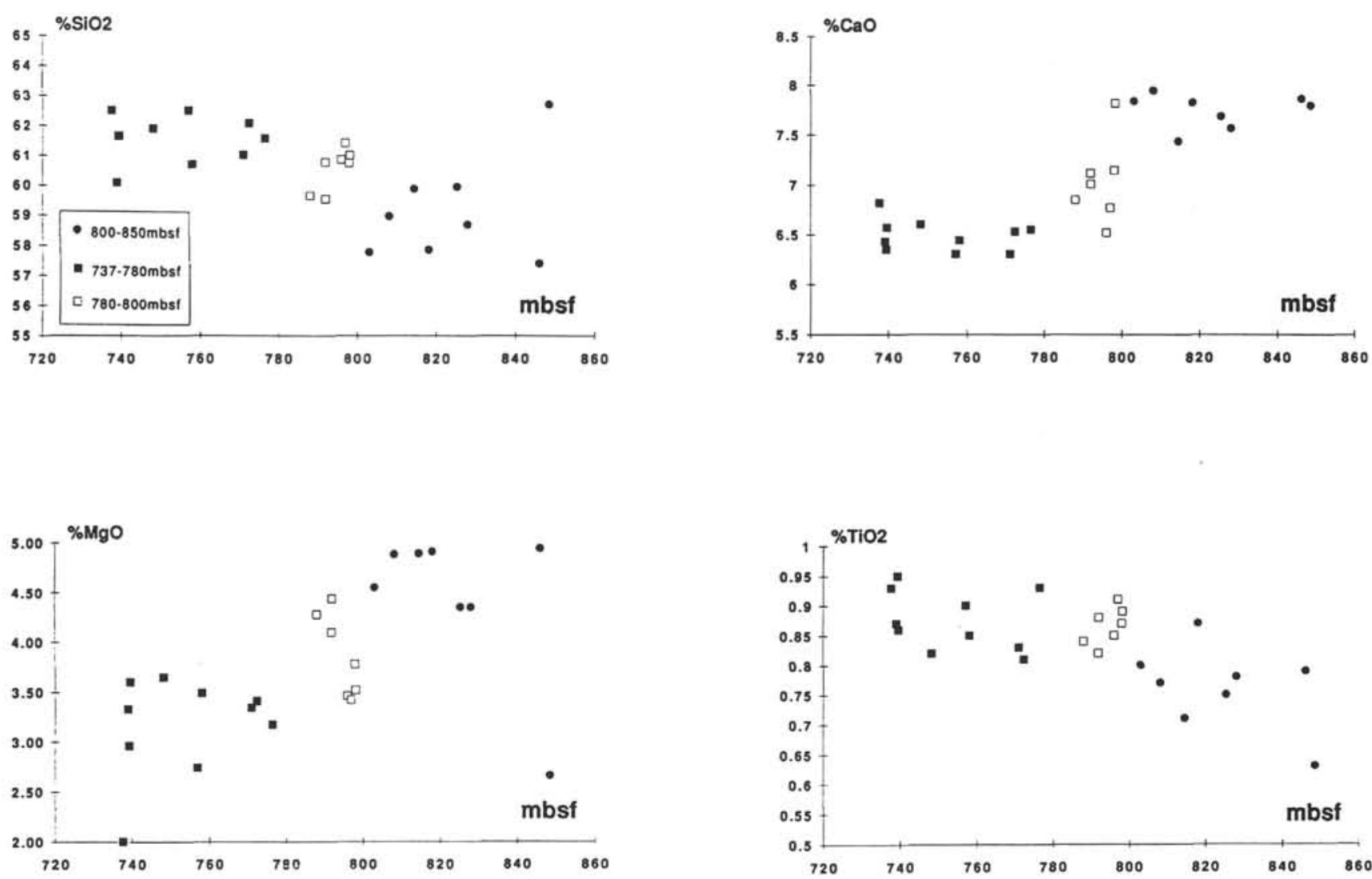

Figure 6. Plots of percentage of $\mathrm{SiO}_{2}, \mathrm{CaO}, \mathrm{MgO}$, and $\mathrm{TiO}_{2}$ vs. depth (mbsf) for volcanic rocks drilled from Bougainville Guyot, Site 831 .

lar $\mathrm{SiO}_{2}$ contents. The Bougainville Guyot lavas, in common with the comparative andesites, all show the conspicuous $\mathrm{Nb}$ anomaly characteristic of subduction-related magmas (Saunders and Tarney, 1979), and high field-strength element (HFSE) abundances from 0.6 to 1 times N-MORB abundances. Clearly, the parental basalts to this suite of andesites were significantly more HFSE-depleted than N-MORB, a characteristic feature of basalts from most intra-oceanic island arcs attributable to a more refractory source peridotite than that which provides N-MORB (Woodhead et al., 1993). However, the guyot samples show only a relatively weak enrichment in LIL elements. Most low- to medium- $\mathrm{K}$ arc basalts and andesites, typified respectively by samples from the Kermadec Arc (L'Esperance KA 15) and the New
Hebrides Island Arc (Epia), show increasing MORB-normalized abundances of elements from $\mathrm{Sr}$ to Ba. Few samples show patterns similar to the Bougainville Guyot andesites. It is difficult to judge whether these low levels of LILE are alteration-enhanced or essentially primary, but as noted above, the remarkably MORB-like $\mathrm{Nd}-\mathrm{Sr}-\mathrm{Pb}$ isotopic signatures of the two analyzed Bougainville Guyot samples indicate minimal LILE-modification of the source peridotite, and suggest that the low and unusual abundances may be near-primary.

In the Leg 134 Initial Reports, reference was made to an unusual enrichment of $\mathrm{Zr}$ relative to $\mathrm{Ti}$ and $\mathrm{Y}$. It is evident from the andesite patterns shown in Figure 9B that for typical intra-oceanic arc basalts and andesites, MORB-normalized $\mathrm{Zr} / \mathrm{Sm}$ values are usually less than 
Table 1 (continued).

\begin{tabular}{|c|c|c|c|c|c|c|}
\hline $\begin{array}{l}\text { Core, section: } \\
\text { Interval }(\mathrm{cm}) \text { : } \\
\text { Zone: }\end{array}$ & $\begin{array}{c}73 \mathrm{R}-2 \\
30-36 \\
\mathrm{rim}\end{array}$ & $\begin{array}{l}83 R-2 \\
59-62 \\
\text { core }\end{array}$ & $\begin{array}{c}83 \mathrm{R}-2 \\
59-62 \\
\text { rim }\end{array}$ & $\begin{array}{l}83 \mathrm{R}-2 \\
59-62 \\
\mathrm{rim}\end{array}$ & $\begin{array}{l}84 \mathrm{R}-1 \\
50-58 \\
\text { core }\end{array}$ & $\begin{array}{c}84 \mathrm{R}-1 \\
50-58 \\
\text { core }\end{array}$ \\
\hline $\mathrm{SiO}_{2}$ & 53.28 & 55.12 & 53.04 & 54.15 & 53.37 & 53.25 \\
\hline $\mathrm{TiO}_{2}^{-}$ & 0.29 & 0.16 & 0.40 & 0.27 & 0.29 & 0.19 \\
\hline $\mathrm{Al}_{2} \mathrm{O}_{3}$ & 0.65 & 1.05 & 1.02 & 1.09 & 0.83 & 0.62 \\
\hline $\mathrm{Cr}_{2}^{2} \mathrm{O}_{3}$ & 0.00 & 0.78 & 0.10 & 0.00 & 0.00 & 0.00 \\
\hline $\mathrm{Fe}_{2} \mathrm{O}_{3}^{3}$ & 0.00 & 0.25 & 1.23 & 1.01 & 0.99 & 1.26 \\
\hline $\mathrm{FeO}^{\circ}$ & 21.41 & 11.11 & 19.32 & 15.16 & 18.93 & 19.73 \\
\hline $\mathrm{MnO}$ & 0.58 & 0.31 & 0.50 & 0.35 & 0.46 & 0.59 \\
\hline $\mathrm{MgO}$ & 21.53 & 29.18 & 23.06 & 26.24 & 23.82 & 23.47 \\
\hline $\mathrm{CaO}$ & 1.72 & 2.05 & 2.15 & 2.07 & 1.60 & 1.29 \\
\hline $\mathrm{Na}_{2} \mathrm{O}$ & 0.03 & 0.00 & 0.02 & 0.01 & 0.03 & 0.01 \\
\hline Total & 99.49 & 100.01 & 100.84 & 100.35 & 100.32 & 100.41 \\
\hline Wo & 3.48 & 3.98 & 4.32 & 4.09 & 3.21 & 2.59 \\
\hline En & 61.30 & 78.73 & 64.54 & 72.02 & 66.43 & 65.54 \\
\hline Fs & 35.22 & 17.28 & 31.14 & 23.89 & 30.35 & 31.87 \\
\hline
\end{tabular}

1. In strong contrast, the average pattern for Bougainville Guyot shows a significant positive $\mathrm{Zr}$ anomaly (i.e., normalized $\mathrm{Zr} / \mathrm{Sm}>1$ ). As HFSE are particularly immune to post-eruption alteration and mobility, this feature is likely to be primary, and demands explanation. Also shown in Figure 6 are patterns for a comagmatic basalt and dacite from Epia submarine volcano in the central part of the New Hebrides Island Arc (Crawford et al., 1988). An important feature of the changing normalized element abundance pattern as differentiation proceeds from basalt to dacite is that the $\mathrm{Zr} / \mathrm{Sm}$ value changes from $<1$ in basalt to $>1$ in dacite. This presumably reflects the more incompatible nature of $\mathrm{Zr}$ than $\mathrm{Sm}$, in clinopyroxene, and leads to the following explanation for the positive $\mathrm{Zr}$ anomaly in Figure 9B for the average Bougainville Guyot andesite. It is suggested here that most of the drilled andesites are, in fact, mixing products of a more evolved porphyritic (plagioclase + pyroxenes) dacitic magma, and more mafic but still significantly fractionated, crystal-poor basaltic magma. An important feature of the Bougainville Guyot andesites that supports this mixing hypothesis is the pronounced compositional zoning of plagioclase, and the reversed zoning and broad Fe-Rich cores of pyroxene phenocrysts.

$\mathrm{Sr}, \mathrm{Nd}$, and $\mathrm{Pb}$ isotopic ratios for two samples from the Bougainville Guyot basement are given in Briqueu et al. (this volume). ${ }^{87} \mathrm{Sr} /{ }^{86} \mathrm{Sr}$ ratios $(0.7028)$, and the single determination of ${ }^{143} \mathrm{Nd} /{ }^{144} \mathrm{Nd}(0.51308)$, are in the MORB range, and there is no displacement from the mantle array towards higher ${ }^{87} \mathrm{Sr} /{ }^{86} \mathrm{Sr}$, a characteristic and widespread, although not ubiquitous feature of arc volcanics, generally attributed to the influence of seawater (e.g., Hawkesworth, 1982). In this respect the Bougainville Guyot sample most closely resembles some of the Mariana intra-oceanic island arc lavas (Woodhead, 1989). Pb isotopic ratios for the guyot samples are distinct from almost all other samples from the New Hebrides Island Arc and from those drilled during Leg 134 , and fall within the MORB field on plots of ${ }^{208} \mathrm{~Pb} /{ }^{204} \mathrm{~Pb}$ vs. ${ }^{206} \mathrm{~Pb} /$ ${ }^{204} \mathrm{~Pb}$ and ${ }^{207} \mathrm{~Pb} /{ }^{204} \mathrm{~Pb}$ vs. ${ }^{206} \mathrm{~Pb} /{ }^{204} \mathrm{~Pb}$, midway between the low ${ }^{206} \mathrm{~Pb} /$
${ }^{204} \mathrm{~Pb}$ field and the high ${ }^{206} \mathrm{~Pb} /{ }^{204} \mathrm{~Pb}$ field defined by data for lavas from the New Hebrides Island Arc from Briqueu et al. (this volume). Overall, the limited isotopic data are essentially MORB-like, and provide little evidence for any ${ }^{87} \mathrm{Sr}$ - and LILE-enriched slab-derived fluid input into the mantle source of these lavas.

\section{REGIONAL TECTONIC IMPLICATIONS}

The DEZ extends in a complex arcuate set of ridges from New Caledonia to the New Hebrides Trench and has been interpreted as an Eocene subduction/obduction zone (Daniel et al., 1977; Maillet et al., 1983). Bougainville Guyot was probably one of a chain of islands that developed in response to southward subduction. A continuation of the same chain of intra-oceanic arc volcanoes may be represented by the volcanoes of the Loyalty Islands east of New Caledonia. Burne et al. (1988) follow Maillet et al. (1983) in regarding the NDR as "37 Ma ocean floor uplifted during middle Miocene time." They go on to suggest that the SDC may represent an "Eocene proto-island arc" formed during subduction along the northern side of the DEZ. The geochemistry of Bougainville Guyot, with a weak subduction-related signature superimposed on a MORB character, is consistent with such an interpretation.

\section{CONCLUSIONS}

1. K-Ar dating suggests an age of approximately $37 \mathrm{Ma}$ for the volcanic succession underlying the carbonate cap of Bougainville Guyot. The 121-m-thick drilled section of volcanic rocks comprises a series of hyalo-breccias or hyaloclastites that have been divided into two groups of alternating subunits. One group appears to be entirely primary and the other includes reworked horizons and oxidized fragments, suggesting a shallow water environment with subaerial input. Variations within the volcanics are attributed to fluctuating water depth.

2. Particularly conspicuous throughout the hyalo-breccias are rounded to wispy blebs with glassy rinds and white, zeolite-filled peripheral fractures. These probably formed by explosive discharge of andesitic magma into seawater, the submarine equivalent of fire-fountaining. The chaotic altered glassy matrix of the hyalo-breccias is the product of more violent interaction during which the andesitic magma and chilled blebs have largely disintegrated. The picture may have been further complicated by avalanches and debris flows of hyalo-breccia moving down the unstable slopes of the submarine volcano.

3. There are variations in the proportion of clasts to matrix, in the total percentage of phenocrysts and in the relative abundance of phenocryst minerals. However, lavas are all two-pyroxene andesites, and individual mineral phases show essentially identical compositional ranges over the entire sequence. Phenocryst pyroxenes and plagioclase are strongly-zoned in oscillatory fashion, although reversed zoning dominates in the cores of the crystals, especially the pyroxenes, attesting to significant magma mixing or repeated changes in the volatile budget of the subvolcanic magma chamber.

Table 2. Electron microprobe analyses of clinopyroxene phenocrysts and groundmass grains from Bougainville Guyot andesitic lavas, Hole 831B.

\begin{tabular}{|c|c|c|c|c|c|c|c|c|c|c|c|c|c|c|c|c|c|c|c|c|}
\hline $\begin{array}{l}\text { Core, section: } \\
\text { Interval (cm): } \\
\text { Zone: }\end{array}$ & $\begin{array}{c}70 \mathrm{R}-2 \\
94-98 \\
\text { rim to op }\end{array}$ & $\begin{array}{c}70 \mathrm{R}-2 \\
94-98 \\
\text { core }\end{array}$ & $\begin{array}{l}70 \mathrm{R}-2 \\
94-98 \\
\text { inter }\end{array}$ & $\begin{array}{l}70 \mathrm{R}-2 \\
94-98 \\
\text { inter }\end{array}$ & $\begin{array}{c}70 \mathrm{R}-2 \\
94-98 \\
\text { micphen }\end{array}$ & $\begin{array}{c}70 \mathrm{R}-3 \\
36-37 \\
\text { sector in }\end{array}$ & $\begin{array}{c}70 \mathrm{R}-3 \\
36-37 \\
\text { rim to op }\end{array}$ & $\begin{array}{c}70 \mathrm{R}-3 \\
36-37 \\
\text { sector in }\end{array}$ & $\begin{array}{l}70 \mathrm{R}-3 \\
36-37 \\
\text { gmass }\end{array}$ & $\begin{array}{l}73 \mathrm{R}-2 \\
30-36 \\
\text { inter }\end{array}$ & $\begin{array}{c}73 \mathrm{R}-2 \\
30-36 \\
\text { core }\end{array}$ & $\begin{array}{c}73 R-2 \\
30-36 \\
\text { core }\end{array}$ & $\begin{array}{l}73 \mathrm{R}-2 \\
30-36 \\
\text { gmass }\end{array}$ & $\begin{array}{l}73 \mathrm{R}-2 \\
30-36 \\
\text { gmass }\end{array}$ & $\begin{array}{c}83 \mathrm{R}-2 \\
59-62 \\
\text { core }\end{array}$ & $\begin{array}{l}83 R-2 \\
59-62 \\
\text { core }\end{array}$ & $\begin{array}{l}84 \mathrm{R}-1 \\
50-58 \\
\text { core }\end{array}$ & $\begin{array}{l}84 \mathrm{R}-1 \\
50-58 \\
\text { core }\end{array}$ & $\begin{array}{c}84 \mathrm{R}-1 \\
50-58 \\
\mathrm{rim}\end{array}$ & $\begin{array}{l}84 \mathrm{R}-1 \\
50-58 \\
\text { gmass }\end{array}$ \\
\hline $\mathrm{SiO}_{2}$ & 51.39 & 52.10 & 52.87 & 51.85 & 51.20 & 51.77 & 51.98 & 51.97 & 51.27 & 51.19 & 52.25 & 52.10 & 51.40 & 52.45 & 52.26 & 50.70 & 51.72 & 51.84 & 51.08 & 52.82 \\
\hline $\mathrm{TiO}_{2}$ & 0.63 & 0.61 & 0.29 & 0.56 & 0.54 & 0.46 & 0.41 & 0.42 & 0.54 & 0.47 & 0.66 & 0.61 & 0.52 & 0.39 & 0.41 & 0.30 & 0.49 & 0.47 & 0.55 & 0.81 \\
\hline $\mathrm{Al}_{2} \mathrm{O}_{3}$ & 2.85 & 1.66 & 2.82 & 1.71 & 3.86 & 1.60 & 3.16 & 3.22 & 0.56 & 3.64 & 2.01 & 1.56 & 2.41 & 0.41 & 1.22 & 2.88 & 1.56 & 1.47 & 1.55 & 3.30 \\
\hline $\mathrm{Cr} \mathrm{O}_{3}$ & 0.26 & 0.00 & 0.22 & 0.05 & 0.12 & 0.18 & 0.05 & 0.21 & 0.00 & 0.00 & 0.18 & 0.00 & 0.29 & 0.00 & 0.00 & 1.14 & 0.04 & 0.02 & 0.03 & 0.03 \\
\hline $\mathrm{Fe}_{2} \mathrm{O}_{3}$ & 2.31 & 1.87 & 0.95 & 1.94 & 1.94 & 1.10 & 1.10 & 0.81 & 0.76 & 1.88 & 1.26 & 1.98 & 2.06 & 0.10 & 1.42 & 2.14 & 2.70 & 2,79 & 3.32 & 0.00 \\
\hline $\mathrm{MgO}$ & 16.64 & 14.06 & 16.40 & 14.59 & 15.29 & 13.92 & 15.94 & 16.43 & 16.78 & 15.15 & 15.09 & 14.19 & 13.81 & 18.02 & 14.51 & 13.30 & 14.73 & 15.20 & 14.44 & 15.78 \\
\hline $\mathrm{CaO}$ & 18.81 & 20.60 & 22.21 & 20.60 & 21.20 & 20.62 & 21.44 & 19.07 & 5.12 & 21.03 & 20.25 & 19.95 & 20.76 & 4.66 & 21.36 & 21.28 & 21.18 & 21.65 & 21.08 & 10.83 \\
\hline $\mathrm{MnO}$ & 0.23 & 0.35 & 0.20 & 0.31 & 0.17 & 0.39 & 0.09 & 0.22 & 0.71 & 0.22 & 0.31 & 0.32 & 0.23 & 0.78 & 0.29 & 03 & 0.2 & 0.23 & 0.30 & 0.48 \\
\hline $\mathrm{FeO}$ & 6.72 & 9.25 & 4.43 & 8.34 & 5.65 & 9.02 & 5.43 & 7.18 & 24.03 & 5.79 & 7.91 & 9.64 & 8.45 & 23.02 & 8.54 & 7.54 & 7.24 & 6.06 & 7.09 & 14.14 \\
\hline $\mathrm{Na}_{2} \mathrm{O}$ & 0.28 & 0.38 & 0.25 & 0.31 & 0.32 & 0.36 & 0.24 & 0.30 & 0.13 & 0.28 & 0.34 & 0.34 & 0.35 & 0.12 & 0.17 & 0.44 & 0.31 & 0.27 & 0.31 & 0.16 \\
\hline Total & 100.12 & 100.88 & 100.64 & 100.26 & 100.28 & 99.41 & 99.84 & 99.83 & 99.90 & 99.65 & 100.26 & 100.69 & 100.28 & 99.95 & 100.18 & 100.05 & 100.21 & 100.00 & 99.74 & 98.35 \\
\hline Wo & 38.39 & 42.06 & 45,05 & 42.03 & 43.83 & 42.87 & 44.02 & 39.51 & 10.59 & 43.42 & 41.45 & 40.56 & 42.79 & 9.52 & 44.09 & 46.34 & 44.57 & 45.38 & 44.91 & 24.50 \\
\hline En & 47.22 & 39.94 & 46.28 & 41.42 & 43.96 & 40.25 & 45.54 & 47.35 & 48.32 & 44.01 & $\begin{array}{l}1.45 \\
43.42\end{array}$ & 40.55 & 40.03 & 51.82 & 41.67 & 40.28 & 43.13 & 44.32 & 42.78 & 49.67 \\
\hline$F_{s}$ & 14.40 & 17.99 & 8.67 & 16.56 & 12.21 & 16.88 & 10.45 & 13.14 & 41.08 & 12.58 & 15.13 & 18.89 & 17.19 & 38.66 & 14.23 & $\begin{array}{l}40.20 \\
13.39\end{array}$ & 12.29 & 10.30 & 12.30 & 25.83 \\
\hline
\end{tabular}


Table 3. Electron microprobe analyses of plagioclase phenocrysts and groundmass grains from Bougainville Guyot andesitic lavas, Hole 831B.

\begin{tabular}{|c|c|c|c|c|c|c|c|c|c|c|c|c|c|c|c|c|c|c|}
\hline $\begin{array}{l}\text { Core, section: } \\
\text { Interval }(\mathrm{cm}) \text { : } \\
\text { Zone: }\end{array}$ & $\begin{array}{c}70 \mathrm{R}-2 \\
94-98 \\
\text { core }\end{array}$ & $\begin{array}{l}70 \mathrm{R}-2 \\
94-98 \\
\text { inter }\end{array}$ & $\begin{array}{l}70 R-2 \\
94-98 \\
\text { core }\end{array}$ & $\begin{array}{c}70 \mathrm{R}-2 \\
94-8 \\
\text { cse zone }\end{array}$ & $\begin{array}{c}70 \mathrm{R}-2 \\
94-98 \\
\text { osc zone }\end{array}$ & $\begin{array}{l}70 \mathrm{R}-2 \\
94-98 \\
\text { gmass }\end{array}$ & $\begin{array}{l}70 \mathrm{R}-2 \\
94-98 \\
\text { gmass }\end{array}$ & $\begin{array}{l}70 \mathrm{R}-3 \\
36-37 \\
\text { core }\end{array}$ & $\begin{array}{l}\text { 70R-3 } \\
36-37 \\
\text { inter }\end{array}$ & $\begin{array}{c}70 \mathrm{R}-3 \\
36-37 \\
\mathrm{rim}\end{array}$ & $\begin{array}{c}70 \mathrm{R}-3 \\
36-37 \\
\text { core }\end{array}$ & $\begin{array}{l}70 \mathrm{R}-3 \\
36-37 \\
\text { inter }\end{array}$ & $\begin{array}{c}70 \mathrm{R}-3 \\
36-37 \\
\mathrm{rim}\end{array}$ & $\begin{array}{l}70 \mathrm{R}-3 \\
36-37 \\
\text { gmass }\end{array}$ & $\begin{array}{c}73 \mathrm{R}-2 \\
30-36 \\
\text { core }\end{array}$ & $\begin{array}{c}73 R-2 \\
30-36 \\
\text { inter }\end{array}$ & $\begin{array}{l}73 R-2 \\
30-36 \\
\text { rim }\end{array}$ & $\begin{array}{c}73 R-2 \\
30-36 \\
\text { core }\end{array}$ \\
\hline $\mathrm{SiO}_{2}$ & 56.56 & 54.17 & 53.83 & 56.69 & 52.86 & 52.70 & 55.73 & 48.97 & 57.20 & 54.97 & 54.55 & 57.54 & 55.38 & 56.35 & 55.81 & 53.81 & 55.26 & 48.34 \\
\hline $\mathrm{Al}_{2} \mathrm{O}_{3}$ & 26.49 & 28.00 & 28.04 & 26.26 & 28.98 & 29.12 & 27.12 & 31.54 & 26.08 & 27.84 & 27.97 & 25.49 & 26.60 & 26.74 & 26.63 & 28.25 & 27.33 & 31.58 \\
\hline $\mathrm{Fe}_{2} \mathrm{O}_{3}$ & 0.63 & 0.62 & 0.72 & 0.76 & 0.68 & 1.15 & 1.10 & 0.57 & 0.83 & 0.57 & 0.72 & 0.69 & 1.02 & 0.85 & 0.44 & 0.85 & 0.91 & 0.72 \\
\hline $\mathrm{MgO}^{\circ}$ & 0.02 & 0.05 & 0.06 & 0.05 & 0.07 & 0.09 & 0.08 & 0.03 & 0.05 & 0.08 & 0.05 & 0.05 & 0.10 & 0.07 & 0.06 & 0.05 & 0.04 & 0.06 \\
\hline $\mathrm{CaO}$ & 10.10 & 11.30 & 11.83 & 10.07 & 12.37 & 12.89 & 10.57 & 16.35 & 9.69 & 11.69 & 11.75 & 9.37 & 10.85 & 10.09 & 10.97 & 13.37 & 11.54 & 16.65 \\
\hline $\mathrm{Na}_{2} \mathrm{O}$ & 5.72 & 5.07 & 4.92 & 5.88 & 4.59 & 4.36 & 5.71 & 2.57 & 6.09 & 5.24 & 5.03 & 6.27 & 5.32 & 5.82 & 5.15 & 4.22 & 5.40 & 2.65 \\
\hline $\mathrm{K}_{2} \mathrm{O}$ & 0.07 & 0.08 & 0.04 & 0.05 & 0.05 & 0.07 & 0.10 & 0.01 & 0.05 & 0.05 & 0.03 & 0.08 & 0.05 & 0.09 & 0.02 & 0.00 & 0.03 & 0.00 \\
\hline Total & 99.59 & 99.29 & 99.44 & 99.76 & 99.60 & 100.38 & 100.41 & 100.04 & 99.99 & 100.44 & 100.10 & 99.49 & 99.32 & 100.01 & 99.08 & 100.55 & 100.51 & 100.00 \\
\hline $\mathrm{Ab}$ & 50.4 & 44.6 & 42.9 & 51.2 & 40.0 & 37.8 & 49.2 & 22.1 & 53.0 & 44.7 & 43.6 & 54.5 & 46.9 & 50.8 & 53.0 & 62.7 & 53.0 & 76.9 \\
\hline Or & 0.4 & 0.5 & 0.2 & 0.3 & 0.3 & 0.4 & 0.6 & 0.0 & 0.3 & 0.3 & 0.1 & 0.4 & 0.3 & 0.5 & 0.1 & 0.0 & 0.2 & 0.0 \\
\hline An & 49.2 & 55.0 & 56.9 & 48.5 & 59.7 & 61.8 & 50.3 & 77.8 & 46.6 & 55.1 & 56.3 & 45.0 & 52.8 & 48.7 & 46.9 & 37.3 & 46.8 & 23.1 \\
\hline
\end{tabular}
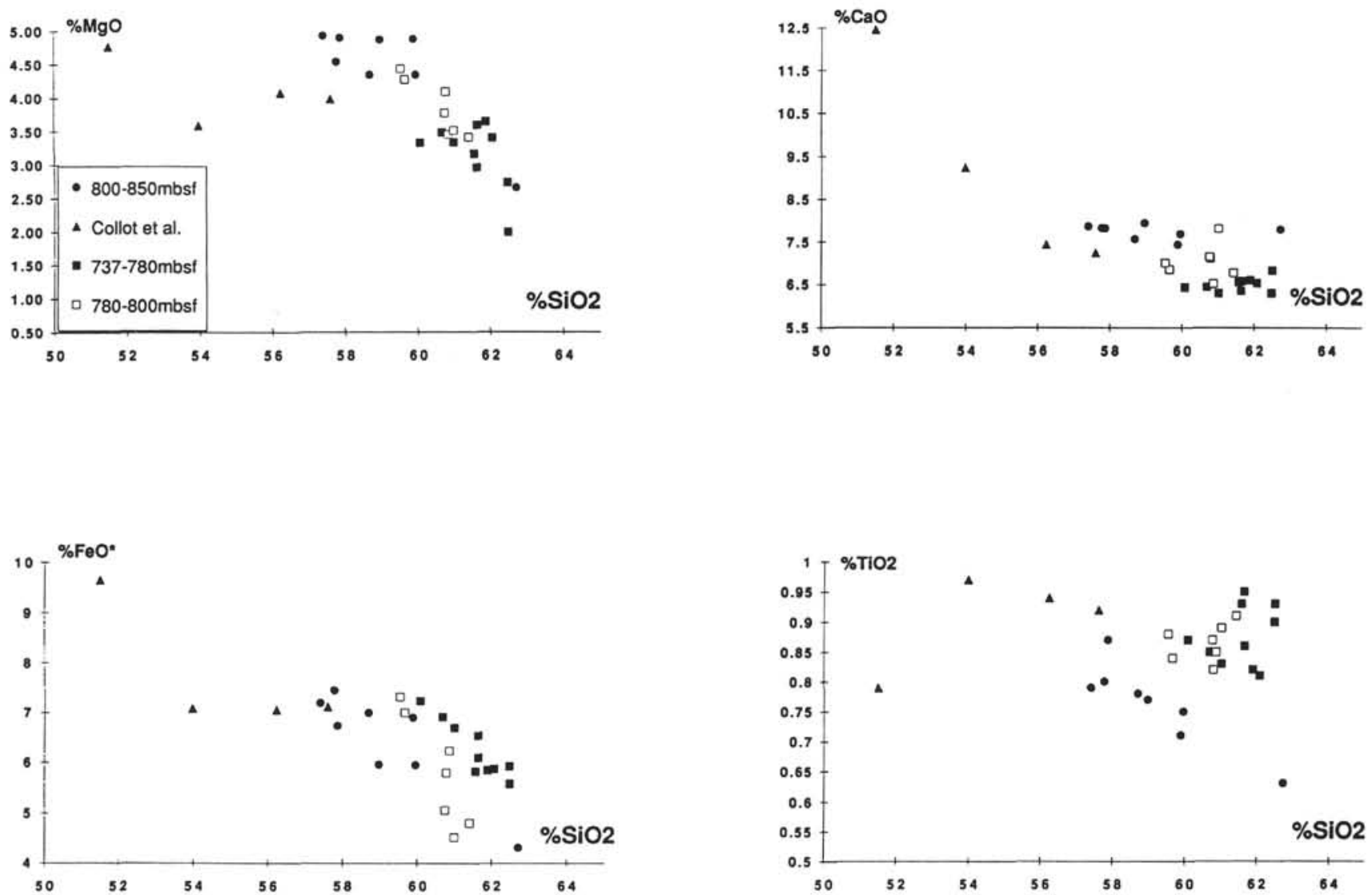

Figure 7. Plots of percentage of $\mathrm{MgO}, \mathrm{CaO}, \mathrm{FeO} *$ (all $\mathrm{Fe}$ as $\mathrm{FeO}$ ), and $\mathrm{TiO}_{2}$ vs. $\mathrm{SiO}_{2}$ for samples drilled (this paper) and recovered by submersible $(\mathrm{Collot}$ et al., 1992) from Bougainville Guyot.

4. Except for the dacite analyzed from close to the bottom of the hole, there is a general increase in $\mathrm{SiO}_{2}$ and a parallel decrease in $\mathrm{CaO}$ and $\mathrm{MgO}$ upsequence.

5. Low $\mathrm{K}_{2} \mathrm{O}$ contents indicate affinities with the low- $\mathrm{K}$ island arc tholeiite series. MORB-normalized trace element patterns indicate only very slight enrichment in LIL elements, but the negative $\mathrm{Nb}$ anomaly and low HFSE abundances relative to MORB are indicative of subduction-related magmatism. Chondrite-normalized REE plots have $(\mathrm{La} / \mathrm{Yb}) \mathrm{N}=1.3-1.9$, but have $(\mathrm{La} / \mathrm{Sm}) \mathrm{N}<1$; they resemble those of some other andesites from low-K intra-oceanic arcs, and those of basalts erupted during early backarc basin opening (e.g., Sumisu Rift and Gulf of California). Limited $\mathrm{Sr}-\mathrm{Nd}-\mathrm{Pb}$ isotopic data are essen- tially MORB-like, showing minimal indication of any input of a LILE-enriched slab-derived fluid.

6. Bougainville Guyot formed as an arc volcanic edifice in an Eocene intra-oceanic island arc developed above a southward-dipping subduction zone.

\section{ACKNOWLEDGMENTS}

We thank the Leg 134 co-chief scientists Jean-Yves Collot and $\mathrm{H}$. Gary Greene, staff scientist Laura Stokking, and Steve Sparks for discussions about Site 831 rocks, and referees Luigi Beccaluva, Lars Borg, and Joe Stolz for significantly improving the manuscript. 
Table 3 (continued).

\begin{tabular}{lrrrrrrr}
\hline $\begin{array}{l}\text { Core, section: } \\
\text { Interval }(\mathrm{cm}):\end{array}$ & $\begin{array}{r}73 \mathrm{R}-2 \\
30-36 \\
\text { Zone: }\end{array}$ & $\begin{array}{r}83 \mathrm{R}-2 \\
59-62 \\
\text { gmass }\end{array}$ & $\begin{array}{r}83 \mathrm{R}-2 \\
\text { core-62 } \\
\text { inter }\end{array}$ & $\begin{array}{r}83 \mathrm{R}-2 \\
59-62 \\
\text { gmass }\end{array}$ & $\begin{array}{c}84 \mathrm{R}-1 \\
50-58 \\
\text { core }\end{array}$ & $\begin{array}{c}84 \mathrm{R}-1 \\
50-58 \\
\text { rim }\end{array}$ & $\begin{array}{r}84 \mathrm{R}-1 \\
50-58 \\
\text { gmass }\end{array}$ \\
\hline $\mathrm{SiO}_{2}$ & 56.22 & 52.74 & 58.12 & 58.98 & 55.69 & 52.40 & 58.98 \\
$\mathrm{Al}_{2} \mathrm{O}_{3}$ & 26.26 & 29.19 & 26.08 & 24.70 & 28.20 & 29.76 & 24.70 \\
$\mathrm{Fe}_{2} \mathrm{O}_{3}$ & 0.93 & 0.35 & 0.56 & 1.46 & 0.39 & 0.52 & 1.46 \\
$\mathrm{MgO}_{\mathrm{CaO}}$ & 0.06 & 0.09 & 0.07 & 0.06 & 0.06 & 0.10 & 0.06 \\
$\mathrm{Na}{ }_{2} \mathrm{O}$ & 10.82 & 13.32 & 9.67 & 8.75 & 11.05 & 13.49 & 8.75 \\
$\mathrm{~K}_{2} \mathrm{O}$ & 5.71 & 4.22 & 6.44 & 6.14 & 5.24 & 3.92 & 6.14 \\
$\mathrm{Total}$ & 0.14 & 0.00 & 0.04 & 0.19 & 0.02 & 0.03 & 0.19 \\
$\mathrm{Ab}$ & 100.14 & 99.91 & 100.98 & 100.28 & 100.65 & 100.21 & 100.29 \\
$\mathrm{Or}$ & 49.7 & 37.4 & 55.6 & 56.3 & 46.1 & 34.4 & 55.3 \\
$\mathrm{An}$ & 0.8 & 0.0 & 0.2 & 1.1 & 0.1 & 0.2 & 1.1 \\
& 49.5 & 62.6 & 44.2 & 42.6 & 53.8 & 65.4 & 43.6
\end{tabular}

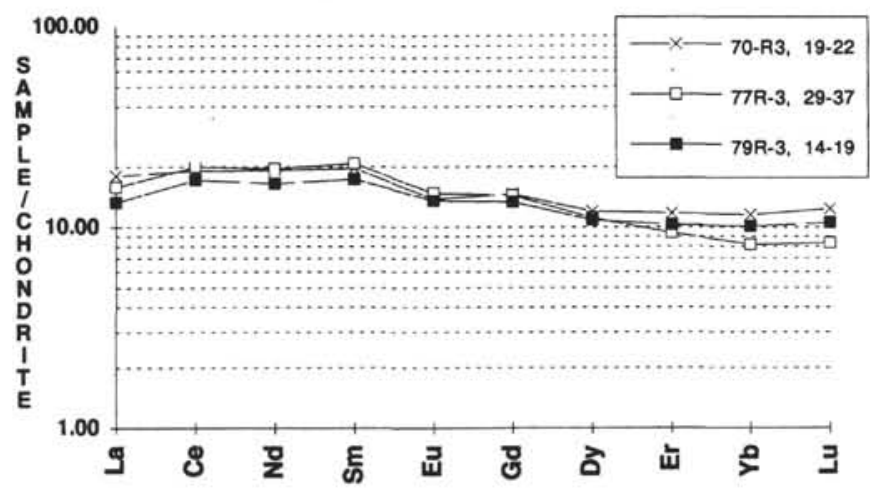

Figure 8. Chondrite-normalized rare earth element plot for three Bougainville Guyot andesites. Normalizing values from Nakamura (1974).

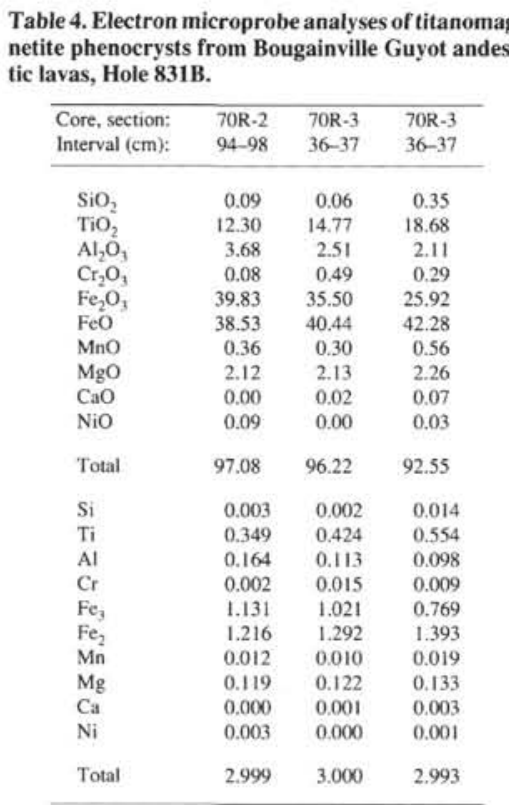

\section{REFERENCES}

Baker, P.E., 1984. Geochemical evolution of St. Kitts and Montserrat, Lesser Antilles. J. Geol. Soc. London, 141:401-411.

- Abbreviations for names of organizations and publications in ODP reference lists follow the style given in Chemical Abstracts Service Source Index (published by American Chemical Society).
BVSP, 1981. Island arc basalts. In Basaltic Volcanism on the Terrestrial Planets: New York (Pergamon), 193-213.

Burne, R.V., Collot, J.-Y., and Daniel, J., 1988. Superficial structures and stress regimes of the downgoing plate associated with subduction-collision in the Central New Hebrides Arc (Vanuatu). In Greene, H.G., and Wong, F.L. (Eds.), Geology and Offshore Resources of Pacific Island Arcs-Vanuatu Region. Circum-Pac. Council Energy Miner. Resour., Earth Sci. Ser., 8:357-376.

Cole, J.W., Graham, I.J., and Gibson, I.L., 1990. Magmatic evolution of Late Cenozoic volcanic rocks of the Lau Ridge, Fiji. Contrib. Mineral. Petrol., 104:540-554.

Collot, J.-Y., Greene, H.G., Stokking, L.B., et al., 1992. Proc. ODP, Init. Repts., 134: College Station, TX (Ocean Drilling Program).

Collot, J.-Y., Lallemand, S., Pelletier, B., Eissen, J.-P., Glaçon, G., Fisher, M.A., Greene, H.G., Boulin, J., Daniel, J., and Monzier, M., 1992. Geology of the d'Entrecasteaux-New Hebrides Arc collision zone: results from a deep submersible survey. Tectonophysics, 212:213-241.

Crawford, A.J., Greene, H.G., and Exon, N.J., 1988. Geology, petrology and geochemistry of submarine volcanoes around Epi Island, New Hebrides Island Arc. In Greene, H.G., and Wong, F.L. (Eds.), Geology and Offshore Resources of Pacific Island Arcs-Vanuatu Region. Circum-Pac. Counc. Energy Miner. Resour., Earth Sci. Ser., 8:301-327.

Daniel, J., Jouannic, C., Larue, B., and Récy, J., 1977. Interpretation of d'Entrecasteaux zone (north of New Caledonia). Int. Symp. on Geodynamics in South-west Pacific. Noumea, New Caledonia, 1976. Paris (Editions Technip), 117-124.

Dubois, J., Deplus, C., Diament, M., Daniel, J., and Collot, J.-Y., 1988. Subduction of the Bougainville seamount (Vanuatu): mechanical and geodynamic implications. Tectonophysics, 149:111-119.

Fisher, M.A., Collot, J.-Y., and Geist, E.L., 1991. The collision zone between the North d'Entrecasteaux Ridge and the New Hebrides Island Arc. Part 2: structure from multichannel seismic data. J. Geophys. Res., 96:4479-4495.

Fisher, R.V., and Schmincke, H.-U., 1984. Pyroclastic Rocks: Berlin (Springer-Verlag)

Gamble, J.A., Smith, I.E.M., McCulloch, M.T., Graham, I.J., and Kokelaar, B.P., 1993. The geochemistry and petrogenesis of basalts from the Taupo Volcanic Zone and Kermadec island arc, Southwest Pacific. J. Volcanol. Geotherm. Res., 54:265-290.

Hawkesworth, C.J., 1982. Isotope characteristics of magmas erupted along destructive plate margins. In Thorpe, R.S. (Ed.), Andesites: Orogenic Andesites and Related Rocks: Chichester (Wiley), 549-571.

Ikeda, Y., and Yuasa, M., 1989. Volcanism in nascent back-arc basins behind the Shichito Ridge and adjacent areas in the Izu-Ogasowara arc, Northwest Pacific: evidence for mixing between E-type MORB and island arc magmas at the initiation of back-arc rifting. Contrib. Mineral. Petrol., 101:377-393.

Maillet, P., Monzier, M., Selo, M., and Storzer, D., 1983. The d'Entrecasteaux zone (southwest Pacific): a petrological and geochronological reappraisal. Mar. Geol., 53:179-197.

Nakamura, N., 1974. Determination of REE, Ba, Fe, Mg, $\mathrm{Na}$, and $\mathrm{K}$ in carbonaceous and ordinary chondrites. Geochim. Cosmochim. Acta, 38:757-776.

Pearce, J.A., 1983. The role of sub-continental lithosphere in magma genesis at active continental margins. In Hawkesworth, C.J., and Norry, M.J. (Eds.). Continental Basalts and Mantle Xenoliths: Nantwich (Shiva Publ.), 230-249.

Saunders, A.D., Fornari, D.J., and Morrison, M.A., 1982. The composition and emplacement of basaltic magmas produced during the development of continental margin basins: the Gulf of California, Mexico. J. Geol. Soc. London, 139:335-346.

Saunders, A.D., and Tarney, J., 1979. The geochemistry of basalts from a back-arc spreading centre in the East Scotia Sea. Geochim. Cosmochim. Acta, 43:555-572.

Woodhead, J., Eggins, S., and Gamble, J., 1993. High field strength and transition element systematics in island arc and back-arc basin basalts: evidence for multi-phase melt extraction and a depleted mantle wedge. Earth Planet. Sci. Lett., 114:491-504.

Woodhead, J.D., 1989. Geochemistry of the Mariana arc (western Pacific): source composition and processes. Chem. Geol., 76:1-24.

Date of initial receipt: 27 March 1992

Date of acceptance: 23 September 1993

Ms 134SR-017 
Table 5. Whole rock X-ray fluorescence analyses for Bougainville Guyot andesitic lavas, Hole 831B, recalculated volatile-free.

\begin{tabular}{|c|c|c|c|c|c|c|c|c|c|c|c|c|c|c|c|c|c|c|c|c|c|c|c|c|c|c|}
\hline $\begin{array}{l}\text { Core, section } \\
\text { Interval (cm) } \\
\text { Depth (mbsf) } \\
\text { Lab }\end{array}$ & $\begin{array}{c}70 \mathrm{R}-1 \\
125-129 \\
737.65 \\
\mathrm{~F}\end{array}$ & $\begin{array}{c}70 \mathrm{R}-3 \\
19-22 \\
739 \\
\mathrm{~F}\end{array}$ & $\begin{array}{c}370 R-3 \\
223-26 \\
739.3 \\
F\end{array}$ & $\begin{array}{c}370-R_{3} \\
631-34 \\
739.5 \\
F\end{array}$ & $\begin{array}{c}371 \mathrm{R}-2 \\
470-74 \\
6748.17 \\
\mathrm{~F}\end{array}$ & $\begin{array}{c}72 R-1 \\
90-94 \\
757 \\
F\end{array}$ & $\begin{array}{c}72 \mathrm{R}-1 \\
134-13 \\
758 \\
\mathrm{~T}\end{array}$ & $\begin{array}{c}94 \mathrm{R}-1 \\
9 \begin{array}{c}17-22 \\
771 \\
\mathrm{~T}\end{array}\end{array}$ & $\begin{array}{c}74 \mathrm{R}-2 \\
78-82 \\
772.38 \\
\mathrm{~F}\end{array}$ & $\begin{array}{c}275 \mathrm{R}-1 \\
2140-43 \\
8776.5 \\
\mathrm{~F}\end{array}$ & $\begin{array}{c}176 \mathrm{R}-4 \\
380-85 \\
5 \\
788 \\
\mathrm{~T}\end{array}$ & $\begin{array}{c}76 \mathrm{R}-5 \\
110-112 \\
791.9 \\
\mathrm{~S}\end{array}$ & $\begin{array}{c}77 \mathrm{R}-2 \\
286-90 \\
792 \\
\mathrm{~T}\end{array}$ & $\begin{array}{c}277 R-3 \\
0 \\
31-34 \\
796 \\
T\end{array}$ & 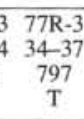 & 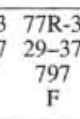 & $\begin{array}{cc}3 & 77 \mathrm{R}-3 \\
7 & 46-50 \\
& 798 \\
& T\end{array}$ & $\begin{array}{c}77 \mathrm{R}-3 \\
139-141 \\
798.14 \\
\mathrm{~S}\end{array}$ & $\begin{array}{c}79 \mathrm{R}-3 \\
14-9 \\
803 \\
\mathrm{~F}\end{array}$ & $\begin{array}{c}80 \mathrm{R}-3 \\
110-115 \\
808.05 \\
\mathrm{~S}\end{array}$ & $\begin{array}{c}81 \mathrm{R}-1 \\
572-76 \\
814.42 \\
\mathrm{~F}\end{array}$ & $\begin{array}{cc}1 & 81 \mathrm{R}-5 \\
6 & 76-82 \\
2 & 818 \\
& F\end{array}$ & $\begin{array}{l}82 \mathrm{R}-2 \\
43-46 \\
825.33 \\
\mathrm{~S}\end{array}$ & $\begin{array}{cc}2 & 82 \mathrm{R}-5 \\
6 & 32-44 \\
3 & 828 \\
\mathrm{~T}\end{array}$ & 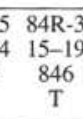 & 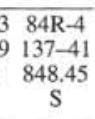 \\
\hline $\mathrm{SiO}_{2}$ & 62.49 & 60.08 & 61.64 & 61.65 & 61.89 & 62.48 & 60.69 & 61.01 & 62.07 & 61.57 & 59.66 & 6079 & 59.54 & 60.87 & 61.42 & 61.42 & 60.76 & $61.01=$ & 57.77 & 58.97 & & & & & & \\
\hline & & $\begin{array}{r}0.87 \\
0.87\end{array}$ & $\begin{array}{r}0.04 \\
0.95\end{array}$ & $\begin{array}{r}1.03 \\
0.86\end{array}$ & 82 & $\begin{array}{r}02.48 \\
0.90\end{array}$ & 0.85 & 0.83 & $\begin{array}{r}0.87 \\
0.81\end{array}$ & 0.93 & $\begin{array}{r}3.00 \\
0.84\end{array}$ & 0.82 & $\begin{array}{r}0.88 \\
0.88\end{array}$ & 0.85 & $\begin{array}{r}0.42 \\
0.91\end{array}$ & $\begin{array}{r}01.42 \\
0.91\end{array}$ & $\begin{array}{r}0.10 \\
0.87\end{array}$ & $\begin{array}{r}0.01 \\
0.89\end{array}$ & 0.80 & $\begin{array}{r}0.77 \\
0.77\end{array}$ & $\begin{array}{l}59.80 \\
0.71\end{array}$ & 0.87 & 0.75 & $\begin{array}{r}0.09 \\
0.78\end{array}$ & $\begin{array}{r}0.79 \\
0.79\end{array}$ & 0.63 \\
\hline $\mathrm{Al}_{2} \mathrm{O}_{3}$ & 17.32 & 16.43 & 16.25 & 16.34 & 16.38 & 16.45 & 16.07 & 16.33 & 16.5 & 17.01 & 16.27 & 16.78 & 15.64 & 16.54 & 17.25 & 17.24 & 17.03 & 17.33 & 16.55 & 17.21 & 16.18 & 17.13 & 16.81 & 16.69 & 16.90 & 17.14 \\
\hline $\mathrm{Fe}_{2}$ & & 1. & 0.95 & 0.88 & & & 1. & & 0.85 & 0.84 & 1.01 & & 1.06 & 0.90 & 0.70 & 0.70 & 0.73 & 0.65 & 1.08 & 0.86 & 1.00 & 0.98 & 0.86 & 1.01 & 1.04 & 0.62 \\
\hline & & 6.28 & 5.68 & 5.30 & 5.08 & & 6.01 & 5.82 & 5.10 & 5.06 & 6.09 & 5.04 & 6.36 & 5.42 & 4.17 & 4.17 & 4.40 & 3.93 & 6.47 & 5.18 & 6.00 & 5.85 & 5.17 & 6.08 & 6.25 & 3.75 \\
\hline $\mathrm{MnO}$ & & 0.12 & 0.12 & 0.12 & 0.11 & 0.11 & 0.12 & 0.12 & 0.12 & 0.10 & 0.16 & 0.15 & 0.13 & 0.09 & 0.08 & 0.08 & 0.16 & 0.14 & 0.14 & 0.13 & 0.15 & 0.15 & 0.12 & 0.13 & 0.16 & 0.06 \\
\hline & & 3.33 & 2.96 & 3.60 & 3.65 & 2.74 & 3.49 & 3.34 & 3.41 & 3.17 & 4.28 & 4.10 & 4.44 & 3.46 & 3.42 & 3.42 & 3.78 & 3.52 & 4.55 & 4.88 & 4.89 & 4.91 & 4.35 & 4.35 & 4.94 & 2.66 \\
\hline & & 6.43 & 6.35 & 6.5 & 6.60 & 6.30 & 6. & 6.30 & 6.53 & 6.55 & 6.8 & & 7.01 & $\begin{array}{l}6.40 \\
6.52\end{array}$ & 6.77 & 6.77 & 7.1 & & 7.8 & & & & & 7.57 & 7.87 & \\
\hline & & & 4.3 & 3. & 3. & & 4. & $\begin{array}{l}0.30 \\
4.48\end{array}$ & 4. & 4.24 & 4. & 3. & $\begin{array}{l}3.01 \\
3.90\end{array}$ & $\begin{array}{l}0.2 \\
4.5\end{array}$ & 4.67 & 4.67 & 4. & & 3. & & & & & 3.95 & $\begin{array}{l}.8 .03 \\
4.03\end{array}$ & \\
\hline & & 0.55 & 0.58 & 0.62 & 0.56 & 0.89 & 0.65 & 0.68 & 0.47 & 0.38 & 0.43 & 0.40 & 0.94 & 0.68 & 0.50 & 0.49 & 0.47 & 0.38 & 0.7 & 0.6 & & 0.44 & 9 & 0.64 & 0.51 & \\
\hline $\mathrm{P}_{2} \mathrm{O}_{5}$ & & 0.12 & 0.13 & 0.13 & 0.13 & 0.12 & 0.13 & 0.12 & 0.13 & 0.14 & 0.16 & 0.12 & 0.11 & 0.11 & 0.12 & 0.12 & 0.11 & 0.12 & 0.11 & $\begin{array}{l}0.0 \\
0.1\end{array}$ & $\begin{array}{l}0.13 \\
0.13\end{array}$ & 0.16 & 0.12 & 0.11 & 0.11 & $\begin{array}{l}0.14 \\
0.10\end{array}$ \\
\hline LOI & & 3.15 & 0.56 & 0.42 & 0.85 & 1.38 & & & 0.64 & 3.29 & & 1.02 & 0.11 & 0.11 & 0.12 & 2.22 & 0.11 & 1.57 & 4.08 & 1.35 & 4.71 & 0.77 & 1.19 & 0.11 & & 1.22 \\
\hline mbsf & 737.657 & 7397 & 739.37 & 739.567 & 748.17 & 757 & $758 \quad 7$ & 771 & 772.387 & 776.57 & 788 & 791.97 & 7927 & 7967 & $797 \quad 7$ & 7977 & 798 & 798.1480 & 803 & 808.058 & 314.428 & $818 \quad 8$ & 325.338 & $828 \quad 8$ & $846 \quad 8$ & 848.45 \\
\hline $\mathrm{SiO}_{2}$ & 62.49 & 60.08 & 61.64 & 61.65 & 61.89 & 62.48 & 60.69 & & 62.07 & 61.57 & 59.66 & 60.79 & 59.54 & 60.87 & 61.42 & 61.42 & 60.76 & $61.01=$ & 57.77 & 58.97 & 59.88 & 57.86 & 59.95 & 58.69 & 57.40 & 62.72 \\
\hline & $\begin{array}{l}42 \\
36\end{array}$ & & & 55 & & 49 & & 51 & 54 & 53 & & 59 & & 53 & & & & 61 & & 63 & 59 & 60 & & & & \\
\hline $\begin{array}{l}\mathrm{Zn} \\
\mathrm{Th}\end{array}$ & 36 & & 70 & & 55 & $\begin{array}{r}66 \\
1\end{array}$ & $\begin{array}{r}63 \\
2\end{array}$ & $\begin{array}{r}63 \\
2\end{array}$ & 52 & $\begin{array}{r}74 \\
3\end{array}$ & 77 & 44 & 67 & 49 & $\begin{array}{r}42 \\
2\end{array}$ & & $\begin{array}{r}46 \\
2\end{array}$ & & & 69 & 45 & 77 & 48 & $\begin{array}{r}65 \\
2\end{array}$ & $\begin{array}{r}82 \\
2\end{array}$ & 49 \\
\hline & 16 & 19 & 24 & 19 & 19 & 18 & 15 & 15 & 19 & 20 & 20 & 22 & $2 i$ & & 21 & 24 & 22 & 27 & 30 & 30 & 36 & 25 & 24 & 28 & 27 & 28 \\
\hline & & & & 19 & & & & 2 . & 22 & & 20 & & & & 19 & & 18 & & & & & & & & & \\
\hline $\mathrm{C}_{\mathrm{t}}$ & 35 & & 74 & 31 & 37 & 49 & 41 & 47 & 29 & 55 & 53 & 35 & 49 & 56 & 72 & & 62 & & & & 58 & 76 & 71 & 82 & 76 & \\
\hline $\mathrm{L}$ & & & & & & & 5 & 5 & & & & & & & & & & & & & & & & & & \\
\hline & 3 & & 7 & 6 & 5 & 6 & & 6 & 5 & 5 & 5 & 4 & 5 & 8 & 4 & & 3 & 3 & & 4 & 6 & 2 & 4 & 4 & 3 & 6 \\
\hline & 1 & 2 & i & 2 & 2 & 1 & 2 & 1 & 2 & 2 & 1 & 1 & i & 1 & 1 & 1 & 1 & 2 & 1 & 1 & 1 & $i$ & 2 & 2 & 1 & 1 \\
\hline $\mathrm{Z}$ & 198 & 139 & 156 & 183 & 184 & 170 & 153 & 152 & 187 & 116 & 151 & 184 & 149 & 135 & 147 & 144 & 140 & 177 & 111 & 154 & 149 & 129 & 158 & 121 & 122 & 160 \\
\hline $\mathrm{Y}$ & 24 & & 29 & 25 & 27 & 29 & 30 & 31 & 28 & 28 & 33 & 25 & 28 & 23 & 22 & & 27 & 27 & & 21 & & 27 & 23 & 24 & 25 & 18 \\
\hline $\mathrm{Sr}$ & 29 & 287 & 283 & 281 & 279 & 291 & 282 & 28 & 284 & 312 & 274 & 275 & 254 & 25 & 275 & 288 & 27 & 273 & 308 & 300 & 342 & 331 & 300 & 307 & 316 & 322 \\
\hline & 2 & 15 & & 1 & 2 & 1 & & 2 & & & & & & & 1 & 16 & & & 14 & & & & & & & \\
\hline & 142 & & 173 & 15 & 15 & 16 & 16 & 16 & 15 & & & 14 & & & 17 & & 15 & 15 & & & & 17 & & & 177 & 171 \\
\hline B & 4 & & 170 & 6. & 64 & 6 & 4 & 3 & & & 35 & 52 & 4 & & 3 & & 4 & & & & & & & & 27 & 55 \\
\hline & 15 & & & 34 & & & 3 & 3 & & & 36 & & 3 & & 6. & & & & & & & & & & 45 & 19 \\
\hline & & 25 & & & & & & & & & & & & & & 16 & & & 16 & & & & & & & \\
\hline & & & & 28.17 & 26.72 & 31.74 & & & & 48.06 & & 26.72 & & & & & & & & & & & & & 38.82 & \\
\hline $\mathrm{Zr} / \mathrm{Y}$ & $\begin{array}{r}8.25 \\
39.26\end{array}$ & & $\begin{array}{r}5.38 \\
32.92\end{array}$ & $\begin{array}{r}7.32 \\
34.37\end{array}$ & $\begin{array}{r}6.81 \\
32.77\end{array}$ & $\begin{array}{r}5.86 \\
33.51\end{array}$ & $\begin{array}{r}5.10 \\
30.15\end{array}$ & $\begin{array}{r}4.90 \\
3053\end{array}$ & 6.68 & $\begin{array}{r}4.14 \\
36.20\end{array}$ & $\begin{array}{r}4.58 \\
30.15\end{array}$ & $\begin{array}{r}7.36 \\
34.62\end{array}$ & $\begin{array}{r}5.32 \\
29.64\end{array}$ & $\begin{array}{r}5.87 \\
33225\end{array}$ & $\begin{array}{r}6.68 \\
31.53\end{array}$ & & $\begin{array}{r}5.19 \\
34.54\end{array}$ & $\begin{array}{r}6.56 \\
35.10\end{array}$ & & $\begin{array}{r}7.33 \\
30.57\end{array}$ & $\begin{array}{r}8.28 \\
33.78\end{array}$ & $\begin{array}{r}4.78 \\
30.68\end{array}$ & $\begin{array}{r}6.87 \\
28.10\end{array}$ & $\begin{array}{r}5.04 \\
26.87\end{array}$ & $\begin{array}{r}4.88 \\
2676\end{array}$ & $\begin{array}{r}8.89 \\
22.09\end{array}$ \\
\hline $\begin{array}{l}\mathrm{Ti} / \mathrm{V} \\
\mathrm{CaO} / \mathrm{A}\end{array}$ & $\begin{array}{r}3.20 \\
0.39\end{array}$ & 0.39 & $\begin{array}{r}32.92 \\
0.39\end{array}$ & $\begin{array}{r}34.31 \\
0.40\end{array}$ & $\begin{array}{r}32.77 \\
0.40\end{array}$ & $\begin{array}{r}35.31 \\
0.38\end{array}$ & 0.40 & $\begin{array}{r}30.53 \\
0.39\end{array}$ & $\begin{array}{r}31.95 \\
0.40\end{array}$ & $\begin{array}{r}36.20 \\
0.39\end{array}$ & $\begin{array}{r}3.13 \\
0.42\end{array}$ & $\begin{array}{r}r 4.62 \\
0.42\end{array}$ & $\begin{array}{r}29.04 \\
0.45\end{array}$ & $\begin{array}{r}22.23 \\
0.39\end{array}$ & $\begin{array}{r}0.39 \\
0.39\end{array}$ & 0.39 & 0.42 & 0.45 & 0.47 & 0.46 & 0.46 & 0.46 & 0.46 & $\begin{array}{r}0.07 \\
0.45\end{array}$ & 0.47 & 0.46 \\
\hline $\mathrm{FeO}$ & 5.579 & 7.225 & 6.535 & 6.092 & 5.845 & 5.924 & 6.91 & 6.693 & 5.865 & 5.816 & 6.999 & 5.796 & 7.314 & 6.23 & 4.8 & 4.8 & 5.057 & 4.515 & 7.442 & 5.954 & 6.9 & 6.732 & 5.944 & 6.989 & 7.186 & 4.308 \\
\hline
\end{tabular}

Note: $\mathrm{LOI}=$ loss on ignition 
Table 6. Rare earth element contents and chondritenormalized values of three Bougainville Guyot andesites, Hole 831B.

\begin{tabular}{lccc}
\hline Core, section: & $70 \mathrm{R}-3$ & $77 \mathrm{R}-3$ & $79 \mathrm{R}-3$ \\
Interval (cm): & $19-22$ & $34-37$ & $14-19$ \\
\hline $\mathrm{La}$ & 5.7 & 5.0 & 4.2 \\
$\mathrm{Ce}$ & 15.6 & 16.3 & 14.0 \\
$\mathrm{Nd}$ & 11.5 & 11.7 & 9.9 \\
$\mathrm{Sm}$ & 3.78 & 4.01 & 3.34 \\
$\mathrm{Eu}$ & 1.0 & 1.07 & 0.98 \\
$\mathrm{Gd}$ & 3.8 & 3.74 & 3.47 \\
$\mathrm{Dy}$ & 3.9 & 3.61 & 3.53 \\
$\mathrm{Er}$ & 2.5 & 2.0 & 2.2 \\
$\mathrm{Yb}$ & 2.4 & 1.7 & 2.1 \\
$\mathrm{Lu}$ & 0.4 & 0.27 & 0.34 \\
$\mathrm{Chondrite}-$ normalized & & & \\
$\mathrm{La}$ & 18.1 & 15.9 & 13.3 \\
$\mathrm{Ce}$ & 19.2 & 20.0 & 17.2 \\
$\mathrm{Nd}$ & 19.3 & 19.6 & 16.6 \\
$\mathrm{Sm}$ & 19.7 & 20.9 & 17.4 \\
$\mathrm{Eu}$ & 13.9 & 14.8 & 13.6 \\
$\mathrm{Gd}$ & 14.7 & 14.4 & 13.4 \\
$\mathrm{Dy}$ & 12.0 & 11.1 & 10.9 \\
$\mathrm{Er}$ & 11.7 & 9.4 & 10.3 \\
$\mathrm{Yb}$ & 11.5 & 8.2 & 10.1 \\
$\mathrm{Lu}$ & 12.4 & 8.4 & 10.5 \\
\hline
\end{tabular}
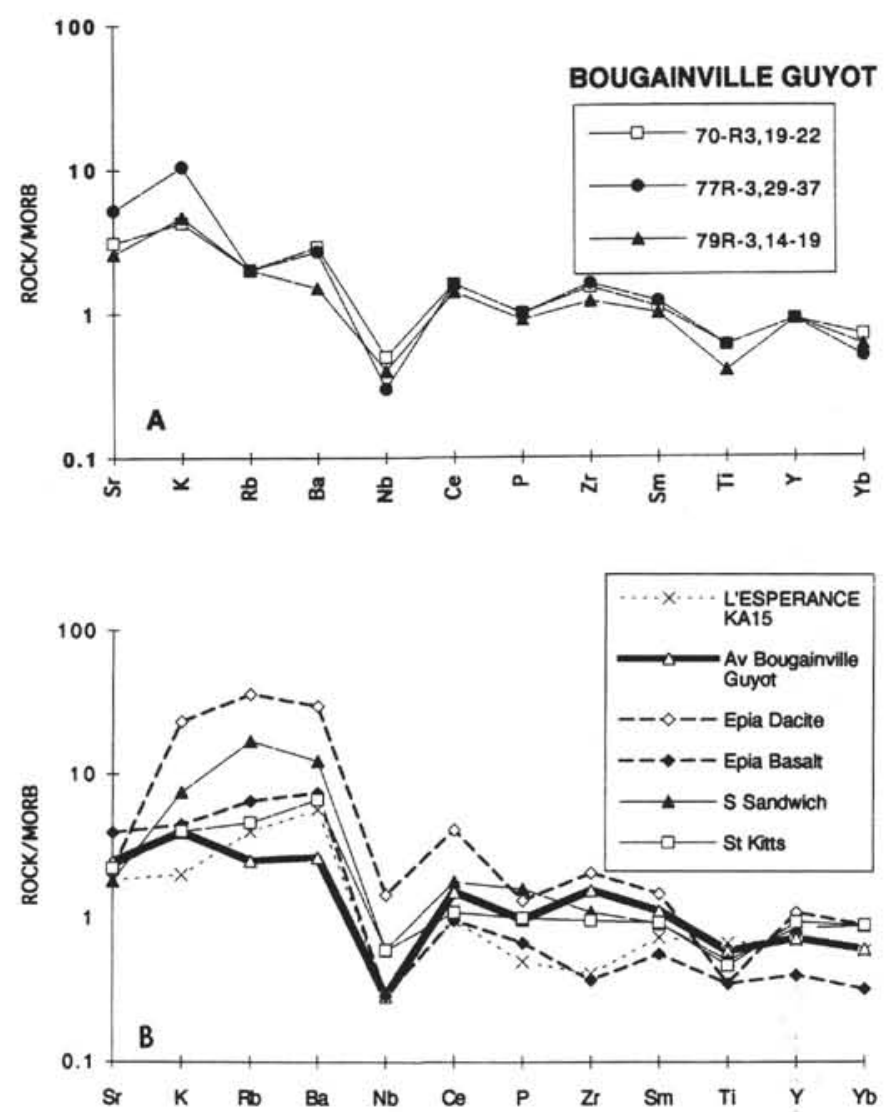

Figure 9. A. MORB-normalized trace element patterns for three andesites from Bougainville Guyot. Normalizing values from Pearce (1983). B. MORB-normalized trace element patterns for five intra-oceanic arc lavas for comparison with the average Bougainville Guyot andesite. KA15 is an andesite from L'Esperance Island in the Kermadec arc (Gamble et al., 1993), SSL 5.1, Leskov Island, South Sandwich Islands (P. Baker, unpubl. data, 1992); 14364, St. Kitts, West Indies (Baker, 1984); Epia basalt and dacite are from Epia submarine volcano, Vanuatu (Crawford et al., 1988). 